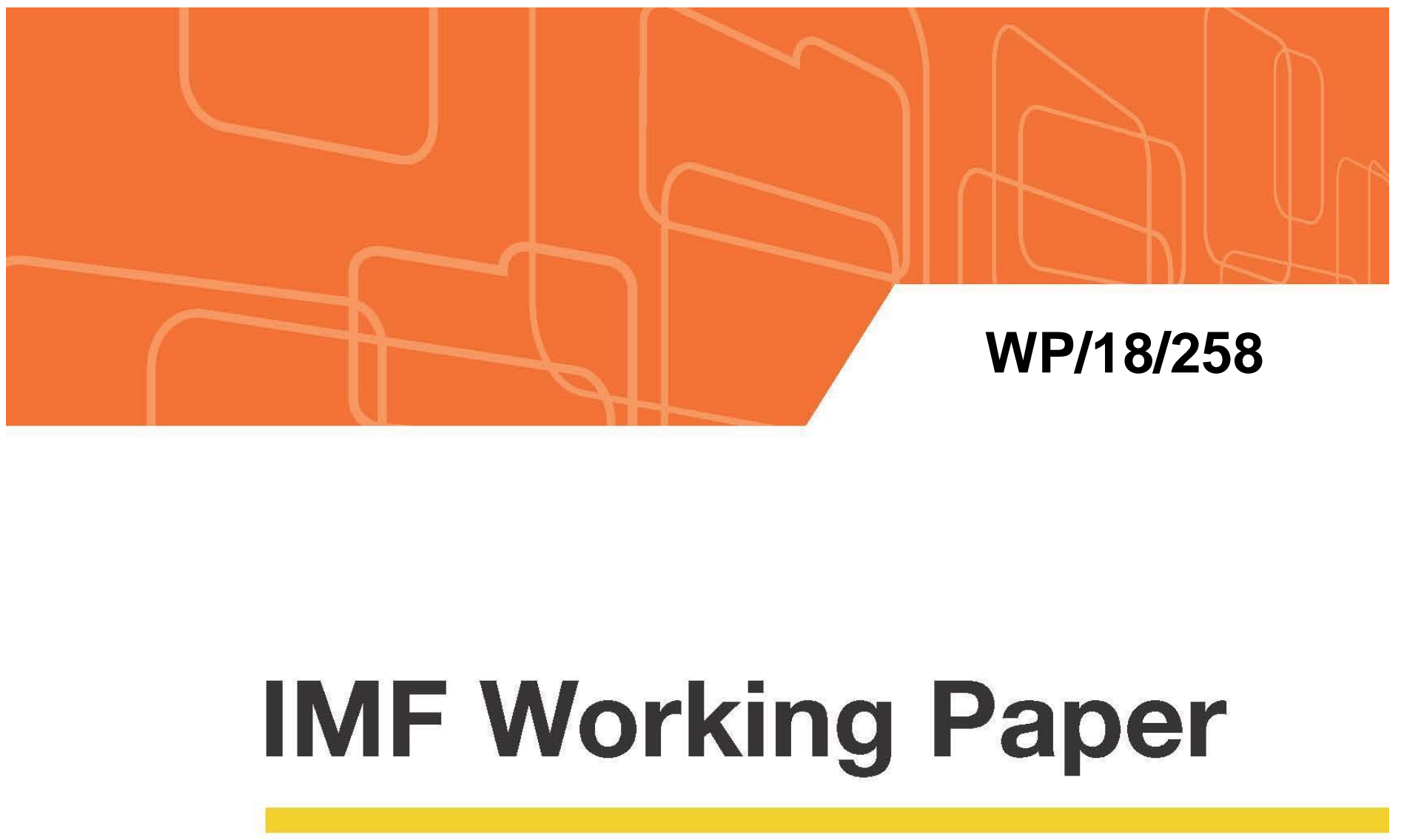

\title{
The Scarcity Effect of Quantitative Easing on Repo Rates: Evidence from the Euro Area
}

by William Arrata, Benoit Nguyen, Imène Rahmouni-Rousseau and Miklos Vari

IMF Working Papers describe research in progress by the author(s) and are published to elicit comments and to encourage debate. The views expressed in IMF Working Papers are those of the author(s) and do not necessarily represent the views of the IMF, its Executive Board, or IMF management. 
Monetary and Capital Markets Department

\title{
The Scarcity Effect of Quantitative Easing on Repo Rates: Evidence from the Euro $\operatorname{Area}^{l}$
}

\author{
Prepared by William Arrata ${ }^{2}$, Benoit Nguyen ${ }^{3}$, Imène Rahmouni-Rousseau ${ }^{4}$ and Miklos Vari ${ }^{5}$ \\ Authorized for distribution by Gaston Gelos
}

December 2018

\section{IMF Working Papers describe research in progress by the author(s) and are published to elicit comments and to encourage debate. The views expressed in IMF Working Papers are those of the author(s) and do not necessarily represent the views of the IMF, its Executive Board, or IMF management.}

\begin{abstract}
Most short-term interest rates in the Euro area are below the European Central Bank deposit facility rate, the rate at which the central bank remunerates banks' excess reserves. This unexpected development coincided with the start of the Public Sector Purchase Program (PSPP). In this paper, we explore empirically the interactions between the PSPP and repo rates. We document different channels through which asset purchases may affect them. Using proprietary data from PSPP purchases and repo transactions for specific ("special") securities, we assess the scarcity channel of PSPP and its impact on repo rates. We estimate that purchasing 1 percent of a bond outstanding is associated with a decline of its repo rate of $0.78 \mathrm{bps}$. Using an instrumental variable, we find that the full effect may be up to six times higher.

JEL Classification Numbers: E52, E58, G10

Keywords: Specialness, repo market, asset purchases, money market

\footnotetext{
${ }^{1}$ This paper previously circulated under the title: "Eurosystem's asset purchases and money market rates". The authors thank Stefania d'Amico, Agnès Benassy-Quéré, Johannes Breckenfelder, Matthieu Bussière, Luis Brandao-Marques, Kelly Eckold, René Garcia, Gaston Gelos, Mattia Girotti, Jean Imbs, Sebastian Infante, John Kandrac, Todd Keister, Thomas King, Antoine Martin, Benoit Mojon, Darmuid Murphy, Anne-Charlotte Paret, Guillaume Plantin, Angelo Ranaldo, Ricardo Reis, Benjamin Sahel, Yu Shi, Tuomas Välimäki, Romain Veyrune, and seminars participants at the Banque de France, the Federal Reserve Bank of Chicago, the IMF, participants to the 2017 ECB workshop on money market and to the 2018 CEBRA conference. All remaining errors are ours. The views expressed in this paper are the authors' and not those of the Bank of France or of the Eurosystem.

${ }^{2}$ Bank of France, Markets Department, william.arrata@banque-france.fr

${ }^{3}$ Bank of France, Monetary Policy and Financial Research Department, benoit.nguyen@ banque-france.fr

${ }^{4}$ Bank of France, Markets Department, imene.rahmouni-rousseau@banque-france.fr

${ }^{5}$ International Monetary Fund, Monetary and Capital Markets Department, mvari@imf.org
} 


\section{Introduction}

The market for repurchase agreements ("repo") allows financial market participants to borrow and lend cash against collateral. It is by far the largest segment of the Euro area money market, with a quarterly turnover of 28,000 billion euros (more than 10 times the amount traded on the unsecured money market (ECB (2015d))). As such, it plays a critical role in the transmission of monetary policy.

Repo rates have gained substantial attention in recent years, after they began moving out of sync with the European Central Ban policy rates (see for instance "Why is the European repo market under pressure?", Financial Times (2016)) ${ }^{1}$. Following the start of the Public Sector Purchase Programme (PSPP) in March 2015 - the European version of quantitative easing $^{2}$ - repo rates not only dropped in negative territory, but declined markedly below the ECB deposit facility rate (DFR), currently set at -40 basis points (bps). This can be seen on Figure 1.

This is all the more surprising given the fact that at this rate, the ECB remunerates the excess reserves of all banks without any limit, in principle preventing transactions on the money market to be concluded at a lower interest rate. Explaining the evolution of repo rates, why they were able to decline below the DFR and how this development could be linked to the Eurosystem's bond purchases will be the main subject of this paper. Answers to these questions have important implications for monetary policy implementation.

We will first consider the impact of the excess liquidity, inherent to any central bank liquidity providing operations on the level of repo rates. Excess liquidity is the liability counterpart of asset purchases. It may be the case that the large amount of central bank reserves created as a byproduct of asset purchases pushed repo rates below the deposit facility rate. This would be reminiscent of the US experience, where money market rates have been below the rate of interest on excess reserves (IOER) since 2008 (see Bech and Klee (2011)).

This mechanism relies on market segmentation and crucially on the fact that banks with access to the central bank's remuneration of reserves acquire some bargaining power on the money market and remunerate non-banks (which do not receive interest on their reserves) at a lower rate. This seems consistent with recent findings on the Eurosystem PSPP (Koijen et al., 2017) showing the final counterparties of asset purchases were mostly counterparties

\footnotetext{
${ }^{1}$ https://www.ft.com/content/7b413b0c-960f-11e6-a80e-bcd69f 323a8b

${ }^{2}$ The ECB Public Sector Purchase Programme started in March 2015 as part of the the ECB asset purchases program. The programme focuses on bonds issued by Euro area governments, public entities and supra-national institutions. It is the largest bond buying program in the history of the Eurosystem, and colloquially known as "Quantitative Easing".
} 
Figure 1: Selected money market rates in the Euro area

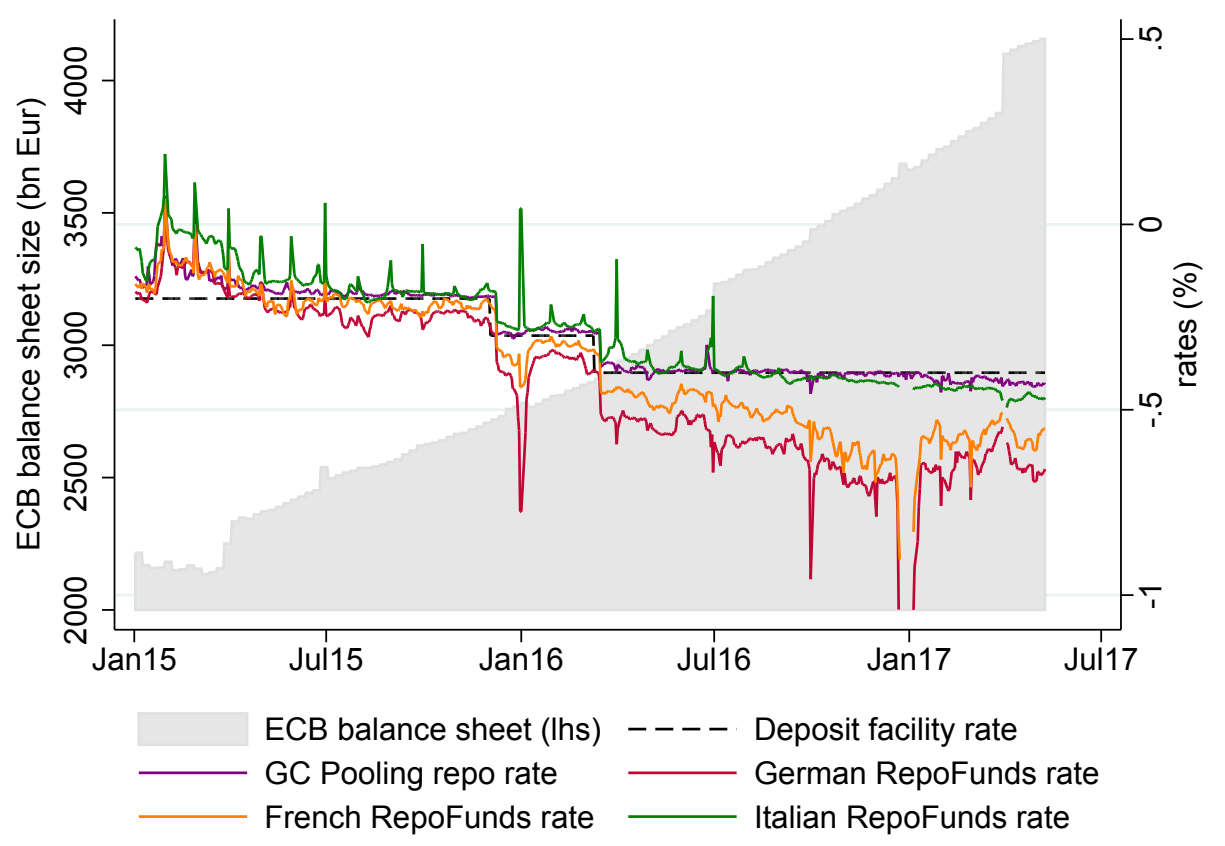

Note: data from Bloomberg, RepoFunds Rate. RepoFunds rates are not shown between the 23th Dec 2016 and 4 Jan 2017 ; and not on 31st March 2017. RepoFunds rates are computed from volume-weighted transactions on Brokertec and MTS platforms, and by large composed of special repo rates. We interpret them as such, as opposed to a General Collateral rates, which GC Pooling is an example of. See http: //www. eurexrepo.com/repo-en/products/gcpooling 
with no direct access to the DFR in the Euro area. According to this hypothesis, the larger the amount of central bank liquidity in the system, the larger should be the gap between money market rates and the DFR. This mechanism is described in more details in section 2.1 and some anecdotal evidence are presented in order to support its empirical relevance.

The bulk of this paper and its main contribution focus however on a different mechanism: the fact that asset purchase have an effect on individual bond scarcity. We will devote most of the empirical analysis to this effect. By purchasing bonds, the Eurosystem decreases the net supply available in the market and makes these bonds all things equal scarcer. Some financial intermediaries may need these bonds for different purposes (for instance to deliver them after a short sale or for regulatory reasons) that we detail in section 2. Since their main motivation to enter in a repo transaction is to borrow this bond against cash, they might be ready to lend their cash at a lower rate. This phenomenon is known as "specialness" (Duffie, 1996). In the presence of specialness, repo rates can decline below the deposit facility rate.

We recover two years of repo transactions data from "Brokertec", the largest electronic platform for European governements bonds repo. We focus on bonds issued by the seven largest Euro area countries, at daily frequency between 2nd January 2015 and 9th May 2017. We investigate at the security level the determinants of repo rates, and whether they are affected by the purchases made by the Eurosystem. For this purpose, we combine data from Brokertec with proprietary data on purchases of Euro area government bonds made under the PSPP program.

Using panel regressions with bond and country-maturity-time fixed effects, our results support the explanation according to which the scarcity of individual bonds affects their specific repo rates: on average, we find that $1 \%$ of a bond outstanding purchased is associated with a decline of about $0.78 \mathrm{bps}$ in its repo rate. We also find that excess liquidity has its own contribution through more aggregated effects.

As the decision by the central bank to purchase a given bond might be influenced by its relative repo rate, we propose an instrumental variable approach to deal with possible endogeneity issues. We make use of pre-determined rules set by the Eurosystem before the start of the programme regarding the maturity and the timing of the purchases. These rules are completely unrelated to the repo market and can explain a sufficient part of the variations in bond purchases. A 2SLS regression shows that, once properly estimated, the effect is found to be 6 times larger than when using OLS. To our knowledge, our paper is the first to estimate the effect of asset purchases on specialness, free of this bias.

Our findings have heavy implications for monetary policy. First, it might be challenging 
for the central bank to pass on one-for-one future policy rate changes in a context of increased dispersion of money market rates. For instance, ECB Executive Board member Benoît Coeuré declared: "there is a risk that, under the current framework, some short-term market rates would not respond fully to changes in our key interest rates or, even if they would, that a continued dispersion of short-term rates would adversely impact the transmission of our monetary policy stance" (Reuters (2018)). In a sense, central banks asset purchases - aiming at flattening the yield curve - might result in partially losing control over the short end of the curve (i.e. money market rates). This trade-off between controlling the short-end and the long-end of the yield curve is likely to play a significant role in the conduct of monetary policy going forward.

To deal with these issues, central banks have several instruments at their disposal. Some are related to the management of excess liquidity when the floor set by the central bank becomes "leaky", including the perimeter of institutions having access to the central bank's facilities. If individual bonds scarcity is the main driver of repo rates deviations, a securities lending facility may alleviate these pressures. Under such a facility, the central bank may lend out the bonds it has purchased.

One additional important policy implication can be drawn from our paper. The existing literature has shown that lower repo rates imply lower yields for the underlying security (Jordan and Jordan (1997)). This means that the effect of asset purchase programs on bond yields could be explained by the abnormally low repo rates that these purchases trigger. In other words, specialness is one of the channels through which central bank asset purchases programs can lower bond yields. ${ }^{3}$

Our paper is related to three strands of literature.

First, we contribute to the empirical literature on bond specialness, that includes for instance Jordan and Jordan (1997), Buraschi and Menini (2002) or Krishnamurthy (2002). More specifically, we study the role of central bank purchases on the specialness premium, like D'Amico et al. (2014), who have conducted a similar exercise in the case of the Federal Reserve's Quantitative Easing and Corradin and Maddaloni (2017), who have explored the impact of Eurosystem's interventions in 2011 on the Italian repo market. The results of these two studies are consistent with ours. Ferrari et al. (2016) also look at the increase in the specialness premium in the euro area but do not use bond-by-bond data for the central bank asset purchases.

\footnotetext{
${ }^{3}$ This is also the conclusion reached by the Swedish authorities, that have had a similar dynamic on their repo market during their assets purchase program (Flodén (2018)).
} 
Second, we make extensive use of the theoretical literature on specialness and in particular of the seminal work of Duffie (1996). Other theoretical contributions include for instance Fisher (2002), Bottazzi et al. (2012) and more recently Huh and Infante (2017) and Duffie and Krishnamurthy (2016). As explained in section 2, our results confirm all the intuitions from this literature.

Third, we also rely on the literature dealing with central bank interventions and money market rates. We will use the results derived in the context of the post-2008 US federal funds markets, to explain part of the decline of money market rates below the deposit facility rate. Contributions to this literature include for instance Bech and Klee (2011), Martin et al. (2015), Garratt et al. (2015) or Armenter and Lester (2017), as detailed in section 2.

The remainder of the paper is organized as follows. Section 2 elaborates on the different mechanisms linking asset purchases and the repo rates. Section 3 describes the data and section 4 outlines our empirical strategy. We then provide our results in section 5 and discuss the policy implications in section 6 . Section 7 concludes.

\section{The repo market and central bank asset purchases: an interplay of different possible mechanisms}

The market for repurchase agreements ("repo") allows participants to borrow and lend cash against collateral, i.e. a security and generally a bond. For this reason, this market is said to be the market for secured funding, as opposed to the unsecured funding market. A repo transaction involves two counterparties: a counterparty A lends 1 euro of cash against a bond $i$ (the collateral) at time $t$, at an interest rate $r$ to a counterparty $\mathrm{B}$. At $t+1$ the trade is reversed. A gets $1+r$ euro of cash and B recovers its bond. A haircut is generally applied to the collateral, that is, one can borrow 95 in cash against 100 of collateral (in this case the haircut is $5 \%$ ).

Some repo transactions are secured by securities from a basket of collateral. Bonds belonging to this basket - and by extension repo transactions made against it - are said to be "General collateral" (GC). In those transactions, the collateral that will be delivered is not known when the trade is negotiated, but the bond is listed in the pre-specified GC basket. The main motivation to enter into a GC repo transaction is a priori to lend/borrow cash (D'Amico et al. (2014), Mancini et al. (2016)). This rate is usually seen as a risk-free money market rate in the literature.

Other repo transactions involve a specific security as collateral. When the repo is ini- 
tiated, it is specified which security (which isin code) has to be delivered against the cash: this market is said to be the special - or specific - collateral repo market (SC). Section 2.3 elaborates on the motives to enter this market and to lend/borrow a specific bond rather than GC. Borrowing a specific bond on the repo market (and thus lend cash), may come at a cost and require to pay a premium for it in the form of a lower remuneration of cash. If for example the GC rate is at $-0.40 \%$, a market participant willing to borrow the German Bund maturing on 15 Aug. 2027 and not another bond, might have to accept to lend its cash at $-0.50 \%$. This "specialness premium" is the subject of sections 2.2 and 2.3 .

In the remainder of this section, we will consider the different possible theoretical mechanisms that could explain how the asset purchases of the Eurosystem caused the decline of repo rates in the Euro area.

\subsection{The General Collateral repo rate and the role of excess liq- uidity}

Several GC rates coexist in the Euro area. A common benchmark for the short-term secured funding is the Stoxx GC pooling (hereafter GC pooling). ${ }^{4}$ It is secured by a basket of around 3000 securities. $^{5}$ GC Pooling has declined in absolute terms and also with respect to the DFR (Figure 2).

A decline in money market rates in the wake of an increase in liquidity does not sound particularly mysterious. First, the "liquidity effect" is well documented both empirically and theoretically. However, theoretical works modeling short term money market rates predict that liquidity should exert downward pressures on interest rates until they reach the deposit facility rate of the central bank (see for instance Ennis and Keister (2008) or Vari (forthcoming) for the Euro area). ${ }^{6}$ This liquidity effect is a simple way to explain what happened in 2015 when repo rates decline toward the deposit facility.

The situation since the second half of 2015, however, violates the de facto relationship

\footnotetext{
${ }^{4}$ See ECB (2015b). Stoxx is the name of the company publishing the interest rate. GC stands for general collateral. "Pooling" is a method of collateral management, where the cash-borrower can substitute securities at any time in his collateral pool.

${ }^{5}$ Only securities rated at least A- are eligible. This basket includes debt issued by Central governments, regional governments and supranational institutions. Some highly rated Covered bonds are also included. Among the seven countries largest Euro area Economies, bonds issued by Spain and Italy are not eligible in the Stoxx GC pooling basket. They are however eligible in the Stoxx GC Pooling Extended basket, which trades a levels close to the simple Stoxx GC Pooling also called Stoxx GC Pooling ECB Basket.

${ }^{6}$ In this paper, we use the term "liquidity" to refer to the amount of central bank liquidity available to banks. This should not be confused with the market liquidity of the securities used in a repo transaction.
} 
Figure 2: GC Pooling, deposit facility rate and excess liquidity

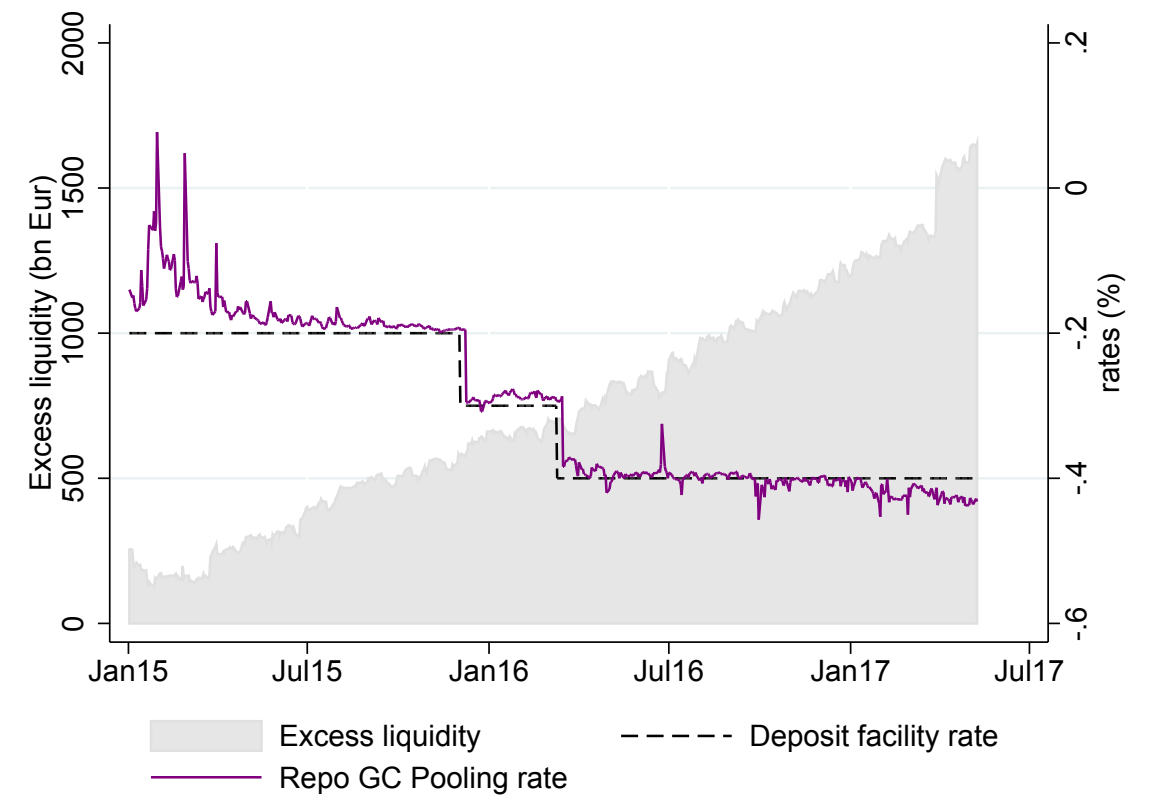

Note: Excess liquidity computed as (current accounts held at the Eurosystem + recourse to the deposit facility - reserve requirements - recourse to the marginal lending facility), source: ECB's Statistical Data Warehouse and Bloomberg.

between the GC rate and the DFR. No agent should be willing to lend their cash below that rate. In the US: Bech and Klee (2011) show that segmentation between banks (which have access to the deposit facility of the central bank) and non-banks (which do not) in an environment of large excess liquidity drove the effective Fed Funds rate below the rate of remuneration of excess reserves. Excess liquidity reinforces the bargaining power of banks that can remunerate the liquidity of non-banks at a rate lower than what they earn by depositing this liquidity at the central bank, thus earning a profit. Applying this framework to the euro area repo market, where similar segmentation exists could explain why the differential between GC repo rates and the DFR persists.

In particular, some participants in the GC Pooling market do not have access to the Eurosystem deposit facility, eg. foreign banks. Thus, they are unable to arbitrage the difference between placing their cash at the central bank and lending it in the repo market. ${ }^{7}$ Moreover, contrary to previous episodes of central bank liquidity expansion by the Eurosystem, the

\footnotetext{
${ }^{7}$ This list is public and can be found on the website of EUREX: http://www.eurexrepo.com.
} 
PSPP is likely to have directly increased cash holdings of non-banks. ${ }^{8}$ Koijen et al. (2017) study how investors have rebalanced their portfolios during the first quarters of the PSPP by selling securities to the Eurosystem. In particular, foreign (that is, non-euro area) investors, which are likely to include a sizable proportion of non-banks, seem to have been substantial sellers to the program.

\subsection{The links between $\mathrm{GC}$ rate(s) and $\mathrm{SC}$ rates}

Besides GC pooling which has the largest collateral basket, there also exists several national GC baskets: a GC basket containing only German sovereign bonds, another one of French sovereign bonds, etc. We construct the time series (see Figure 3a) of those national GC repo rates from transactions against these baskets made in the repo platform Brokertec. Section 3 describes the database in more details.

We first observe that there is a clear hierarchy between the different repo rates, presumably reflecting credit risk or particular services offered by GC of certain countries. ${ }^{9}$ Interestingly, end of quarter and end of year seem to be responsible for heightened volatility, reflecting also sometimes opposite patterns between core and peripheral euro area countries. This strongly suggests that banks swapped their securities at end of accounting periods. This aspect is documented in the US for instance by Duffie and Krishnamurthy (2016) and related to the implementation of the Supplementary Leverage Ratio (SLR).

Second, we observe that GC repo rates have been diverging since 2016, as shown on Figure 3b. Interestingly, GC rates in Italy and Spain seem to remain effectively bounded by the deposit facility rate. In Germany and France, GC repo rates trade at significantly lower levels, suggesting that excess liquidity affects differently the different euro area jurisdictions. A simple elasticity analysis suggest that beyond 500 billion euro of excess liquidity, Italian and Spanish GC remain muted and floored by the DFR, while each extra 1 billion euro of excess liquidity is associated with -1 bps in the German and in the French GC. This makes sense in a world where market participants without access to the DFR have strong preferences to park their liquidity against core countries GC, for instance.

\footnotetext{
${ }^{8}$ By contrast, the two 3-year LTROs launched in late 2011 and early 2012 injected liquidity primarily in the banking sector since only banks are eligible to borrow from the Eurosystem, the liquidity might have channeled the financial system differently.

${ }^{9}$ This could seem surprising given that these transactions are cleared by central counterparties (CCP) (as explained at the beginning of this section). CCP already apply haircuts that should take into account the difference of credit risk of each underlying collateral. Boissel et al. (2014) suggest that divergence between GC rates of European countries could be explained by the pricing of the tail risk that in some states of the world CCPs might default, letting repo market participants with a direct exposure to collateral credit risk.
} 
Figure 3: GC repo rates divergence by jurisdiction

Panel (a) shows GC rates by countries, computed as the daily volume-weighted average of rates on trades made against GC baskets in Brokertec. For sake of clarity, we drop data between the last week of December 2016 and first week of January 2017. Panel (b) shows a scatterplot of the spread of each country GC rate against the deposit facility rate and the level of excess liquidity.

(a) GC repo rates for selected countries

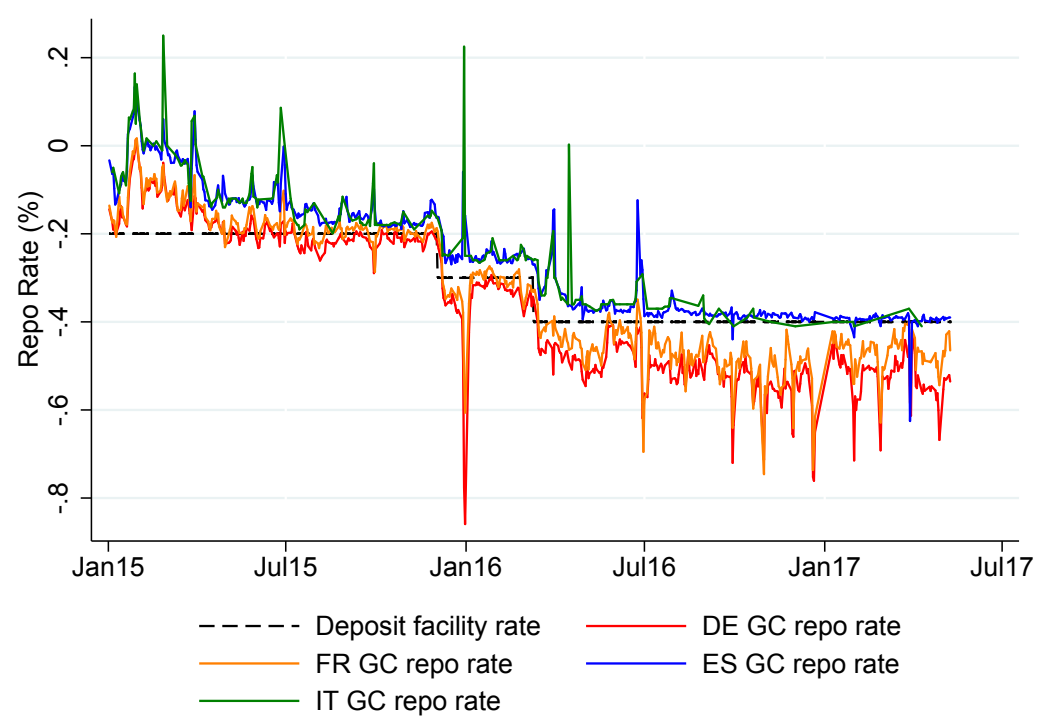

(b) Spread of each GC repo rate against the deposit facility rate and excess liquidity. Data shown up to 1500 bn EUR of excess liquidity.

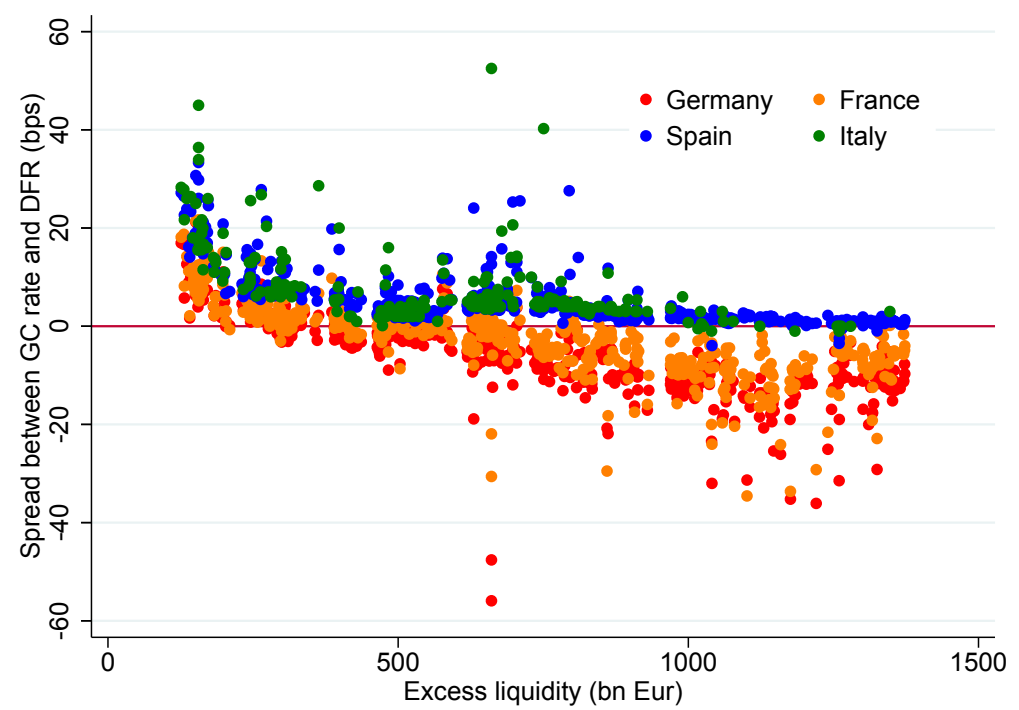


On Figure 4 we plot country GC rate vs. SC rates for the bonds of the same countries. It shows a large dispersion of SC rates, with some bonds trading sometimes 100 basis points below the country-GC rate. In each country, GC rates behave as the upper envelope of SC rates. This makes perfect sense given that the holder of a bond that could be lent both in a GC basket or in the SC market has no reason go to the GC market if this bond has a specialness premium, and if it can be used to to borrow cash below the GC rate. Conversely, if the $\mathrm{SC}$ rate was higher than the $\mathrm{GC}$ rate, there would be an arbitrage opportunity. In that case, one could make profit by borrowing the security at the $\mathrm{SC}$ rate and lending it at the $\mathrm{GC}$ rate.

Figure 4: Euro area's 4 largest countries GC and distribution of SC repo rates

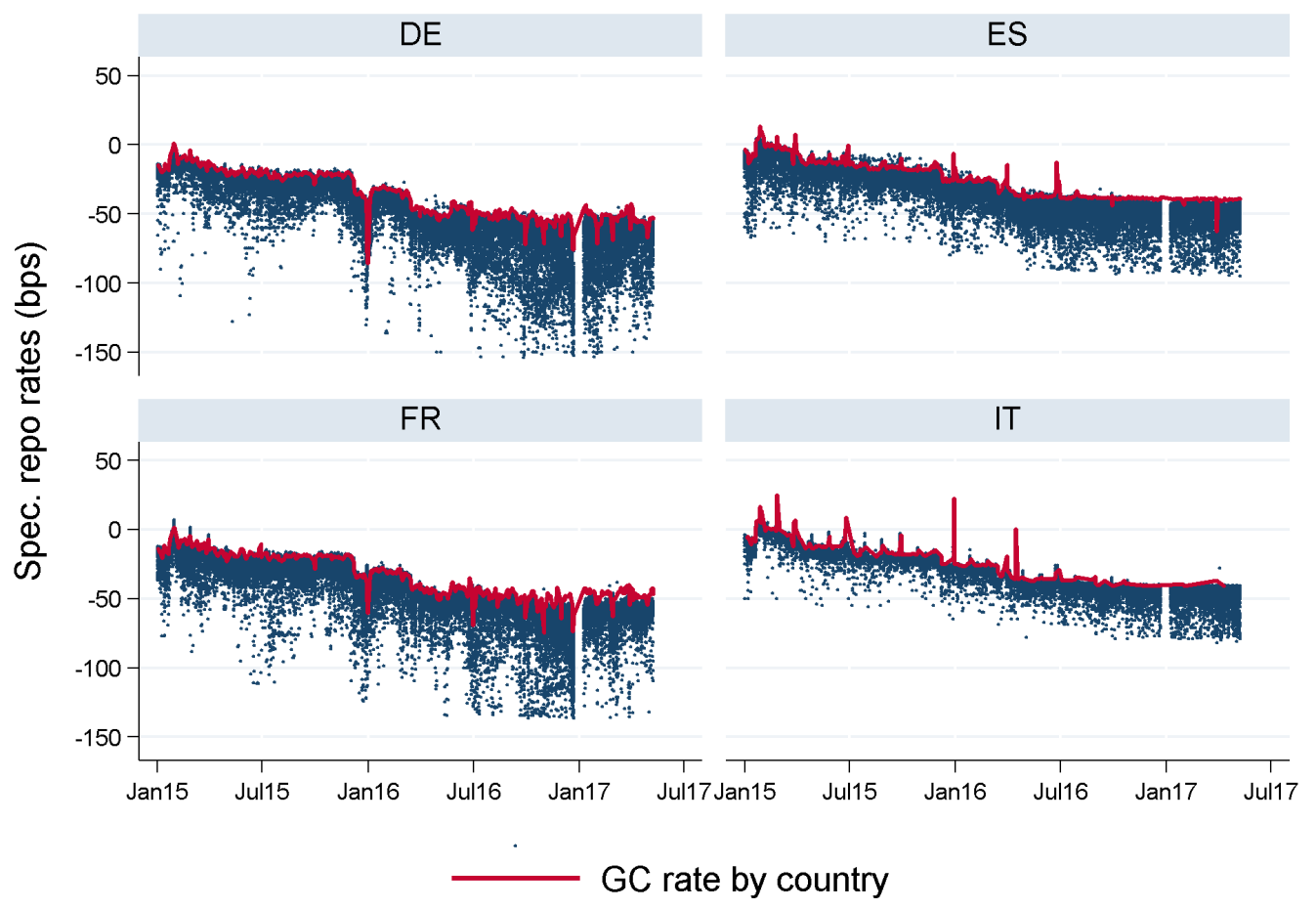

Note: Each dot corresponds to a specific security daily SC repo rate. This SC repo rate is computed as the daily volume-weighted average of SC transactions on each day on this specific security. GC rate is computed from averaging the rates of repo transactions made against each country GC basket. Same figure for all 7 countries of our sample in annex.

These observations lead us to consider the following possibility: it could be the case that bonds in some countries are so scarce, that they all have values on the repo market. As a result, GC rates do not reflect risk-free funding rates (as it is often assumed in the literature) 
but instead just the highest SC rates, and are below where the risk-free rate should be (if we were able to observe it). When all bonds are valuable in the $\mathrm{SC}$ repo market, the GC rate is not necessary reflecting a risk free rate and the GC-SC spread (the specialness premium) is not an accurate measure of the value of a bond on the repo market. In our empirical analysis we will therefore use the SC rate instead of the GC-SC spread.

\subsection{The effect of bond scarcity on $\mathrm{SC}$ repo rates}

\subsubsection{The theoretical mechanism behind specialness}

Following Duffie (1996), we assume that some specific securities are actively sought out in the repo market. This happens for instance when a financial intermediary "short sells" a security (i.e. sells a security he currently does not possess). In order to deliver the security, the financial intermediary might either try to buy it in the bond market, or borrow the security in the repo market at the SC rate ${ }^{10}$. The "specialness premium" is the difference between the GC rate and the SC rate of the security.

A key friction in Duffie's model is that some holders might be unwilling to lend these securities at the GC rate, but only at some lower rate, the SC rate, and thus demand a specialness premium to lend their bonds. The supply curve is therefore upward sloping ${ }^{11}$

The demand for collateral, in the form of reverse repos, emanates from short sellers, who must find the securities to avoid failing on their deliveries. Thus, for a given size of short positions in the security market, the demand from shorts is inelastic to the SC rate of the

\footnotetext{
${ }^{10}$ Failing to return a bond at the term of a repo transaction triggers a complex process in Europe, depending on types of agreements signed by the counterparties and largely based on market practices. In the worst case scenario, fail may put a counterparty in default. Most of the time, however, there is a agreement to defer the restitution of collateral. In this case, the repo continues interest-free for the counterparty holding cash. However, as noted by ICMA (see https://www.icmagroup.org/Regulatory-Policy-and-Market-Practice/ repo-and-collateral-markets/icma-ercc-publications/frequently-asked-questions-on-repo/ 40-what-happens-to-repo-transactions-when-interest-rates-go-negative/), negative repo rates may create a pervasive incentive to fail to deliver the collateral. Thus, market practice in CCPs evolved toward passing the negative cost of bearing cash for the failed counterparty to the failing counterparty. Euroclear for instance remunerates cash balances over 150 million euro at -70bps since end 2016, see http: //www.clearstream.com/clearstream-en/products-and-services/asset-types/cash/a16162/83886 and this cost will be charged to the failing counterparty.

${ }^{11}$ The link between bond outstanding in the outright market and quantities available for lending in the repo market is not necessarily straightforward Bottazzi et al. (2012). The total amount outstanding of a given bond is not necessarily made available for loan in the repo market. Conversely, quantity lent in the repo market may also result from reuse. "Reuse" is the activity performed on the repo market whereby agents having borrowed a security will lend again the collateral. This is explored for instance by Singh (2011) with the idea of "velocity of collateral" i.e., the number of times a given unit of collateral is lent, which affects the total supply of collateral.
} 
security. ${ }^{12}$

Figure 5 illustrated the SC repo market supply and demand for a given security. The horizontal axis measures the specialness premium. The vertical axis measures the quantity available for trade in the repo market. Supply and demand of collateral for all possible levels of Spec premium are displayed, holding constant the positions of agents in the bond market. Figure 5 also shows the effect of a reduction of supply and an increase in demand, which is what has happened in the Eurosystem in recent years, as argued in the next subsection.

Figure 5: Impact of supply and demand shocks in the SC repo market

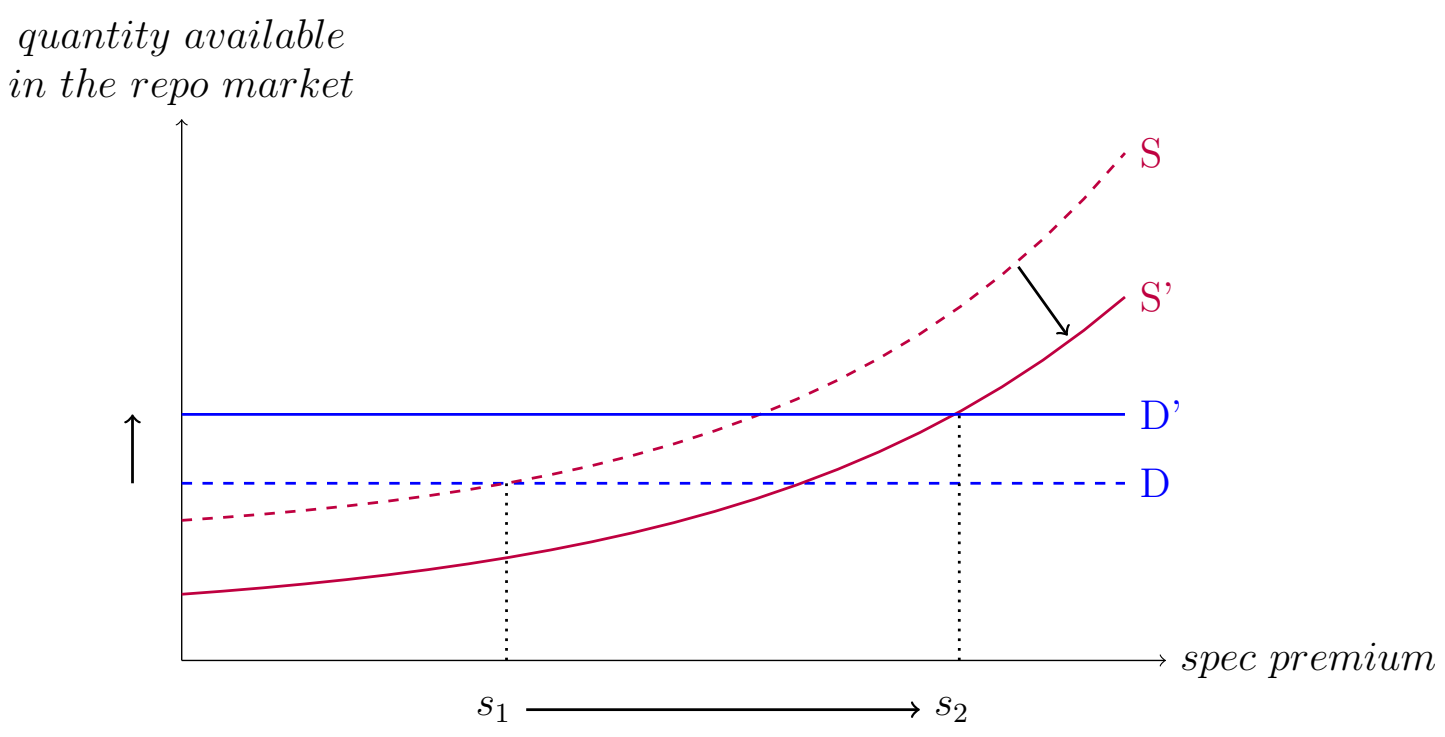

\subsubsection{Supply and demand shocks in the SC market}

Equipped with these theoretical foundations, one can figure out the impact of the PSPP on the repo market.

The Eurosystem announced on 22th January 2015 the expanded Asset Purchase Program $(\mathrm{APP})^{13}$, to provide additional monetary policy stimulus to "help to bring inflation back to

\footnotetext{
${ }^{12}$ The short seller would not find it less costly to purchase the security on the outright market. Indeed, the increase in specialness translates into an increase in the price of the security. As holders of the bond trading on special can potentially borrow money below other market rates, the security incorporates an additional value, referred to as "repo dividend" by Fisher (2002). This repo dividend implies that everything else constant, a bond trading on special on the repo market will have a higher price on the bond market.

${ }^{13}$ Expanded APP merged the two existing asset purchase programs - CBPP3 on European covered bonds market and ABSPP on ABS market - with a new program on European sovereign bonds (PSPP). Details
} 
levels in line with the ECB's objective" and support credit conditions, "a precondition for inflation to return to and stabilise at levels close to 2\%."14 The extended package included for the first time purchases of sovereign bonds from all jurisdictions ${ }^{15}$ under the PSPP (Public Sector Purchase Program). Purchases started in March 2015 at a pace of around 50 billion euro a month for Euro area government bonds. As of May 2017 (the end of our sample), the Eurosystem held 1500 billion euro of government bonds, among which around 900 billion euro are rated at least single $\mathrm{A}$. The total Euro area sovereign bond market represents around 7,500 billion euro, according to the ECB. ${ }^{16}$ We argue that the the Eurosystem's PSPP probably triggered a rise in short selling. Indeed, by purchasing bonds on the open market, central banks might directly lead their counterparties to short sell the bonds to them. Counterparties are then left with a short position. ${ }^{17}$

On the supply-side, several forces could have contributed to decrease the supply of collateral in the Euro area. First, the quantity of securities available for lending in the repo market might have decreased. For instance, it seems that many regulatory constraints force financial intermediaries to hold certain bonds and might prevent them from lending these bonds out on the repo market. Those constraints began to enter into force since 2015 onward, and a non-exhaustive list can be found in appendix A. Several pieces of regulation such as the Leverage Ratio (LR) or the Liquidity Coverage Ratio (LCR) penalize the use of repos by banks. As a result, banks might not be able to intermediate trades between some of their clients willing to lend securities to the market and institutions that are short of the bonds. Everything else equals, this lack of arbitraging capacity should allow larger specialness premia to persist.

can be found on the ECB website here: https://www.ecb.europa.eu/mopo/implement/omt/html/index . en.html

${ }^{14}$ See https : //www.ecb.europa.eu/explainers/tell-me-more/html/asset-purchase.en.html

${ }^{15}$ As of May 2017, the Eurosystem has not purchased any Greek bonds.

${ }^{16}$ https://www.ecb.europa.eu/stats/ecb_statistics/escb/html/table.en.html?id=JDF_SEC_OAT_ DEBT_SECURITIES\&period=2017-05

${ }^{17}$ A large part of the literature on short-selling focuses on the so-called on "on-the-run" bonds, which are special. These bonds are special because they are heavily short-sold by primary dealers to their clients (see for instance Duffie (1996), Fisher (2002), Krishnamurthy (2002), D'Amico et al. (2014) among others). Other bonds which are subject to heavy short-selling activity are bonds included in the basket of future contracts and that are the "cheapest to deliver" (Buraschi and Menini (2002). At last, short selling is used in anticipation of a decrease in the price of the security. 


\section{Data}

\subsection{Repo transactions data}

The repo market represents around $60 \%$ of the money market, compared to less than $5 \%$ for the unsecured market $(\mathrm{ECB}(2017 \mathrm{~b})) .{ }^{18}$ Within the repo market, the daily turnover of SC (mostly on the MTS and Brokertec platforms) was around 200 billion euro daily in the first quarter of 2017 (Coeuré (2017a)), more than 20 times the size of the GC pooling market (on the Eurex platform). ${ }^{19}$ Brokertec is by far the largest of the two platform dedicated to special trades (Dunne et al., 2013). Overall, we are confident that our database on SC trades covers the largest segment of the Euro area money market and that the interest rates we observed are the most representative available. We focus on the one-day maturity, the "spot-next" tenor, which is the most traded in our dataset $(67 \%) .{ }^{20}$

The raw data report slightly more than 5 million trades between January 2, 2015 and May 9, 2017, collateralized with 1,282 different ISINs, representing either a basket (in the case of GC transactions) or specific securities used as collateral. The vast majority of transactions made in Brokertec concerns the SC repo market ( $87 \%$ on average during the period) and this share has increased since January 2015 (see Fig6).

Almost all transactions in Brokertec are cleared through a central counterparty (LCH Repoclear) in charge of applying a public haircut schedule to the collateral depending on the issuer country and the residual maturity. We will not focus on these haircuts in the paper as they were relatively stable during our period under review. In any case, as they are defined for each issuer country for given maturities, they will be captured by maturity-bucket, issuer country and time fixed effects in our regressions.

\footnotetext{
${ }^{18}$ The remaining $35 \%$ are derivatives (foreign exchange swaps and overnight index swaps). It implies that among non-derivative product, repo represent $92 \%$ of the money market.

${ }^{19}$ See also ICMA: http://www.icmagroup.org/Regulatory-Policy-and-Market-Practice/repo-andcollateral-markets/frequently-ask ed-questions-on-repo/41-mapping-the-interdealer-european-repo-market/ The secured market represents by far the largest market segment of euro area money markets, with $41 \%$ of total turnover in 2015, while the unsecured market segment accounts for only $4 \%$ of the market (ECB Euro Money Market Survey, 2015). The infrastructures on which the euro secured market operates are detailed in Mancini et al. (2016). It can be broken down among bilateral, triparty and CCP-based operations. As of 2013, trading via CCPs stands for $71 \%$ of total market, up from $42 \%$ in 2009. Also, the vast majority of repos with government bonds and other relatively safe securities transit via CCPs.

${ }^{20}$ The so- called "spot-next" tenor covers arrangement that have a one-day maturity and where the first leg of the agreement is settled two days after it is concluded, i.e. cash and securities are being exchange first two days after this was agreed. The arrangement is then reversed (cash and securities are being exchanged again) three days after the agreement has been concluded. This timing is convenient to deliver securities that one has sold but does not have, given that by convention securities delivery take place two days after they have been purchased/sold.
} 
Figure 6: Daily volumes traded against SC and GC collateral

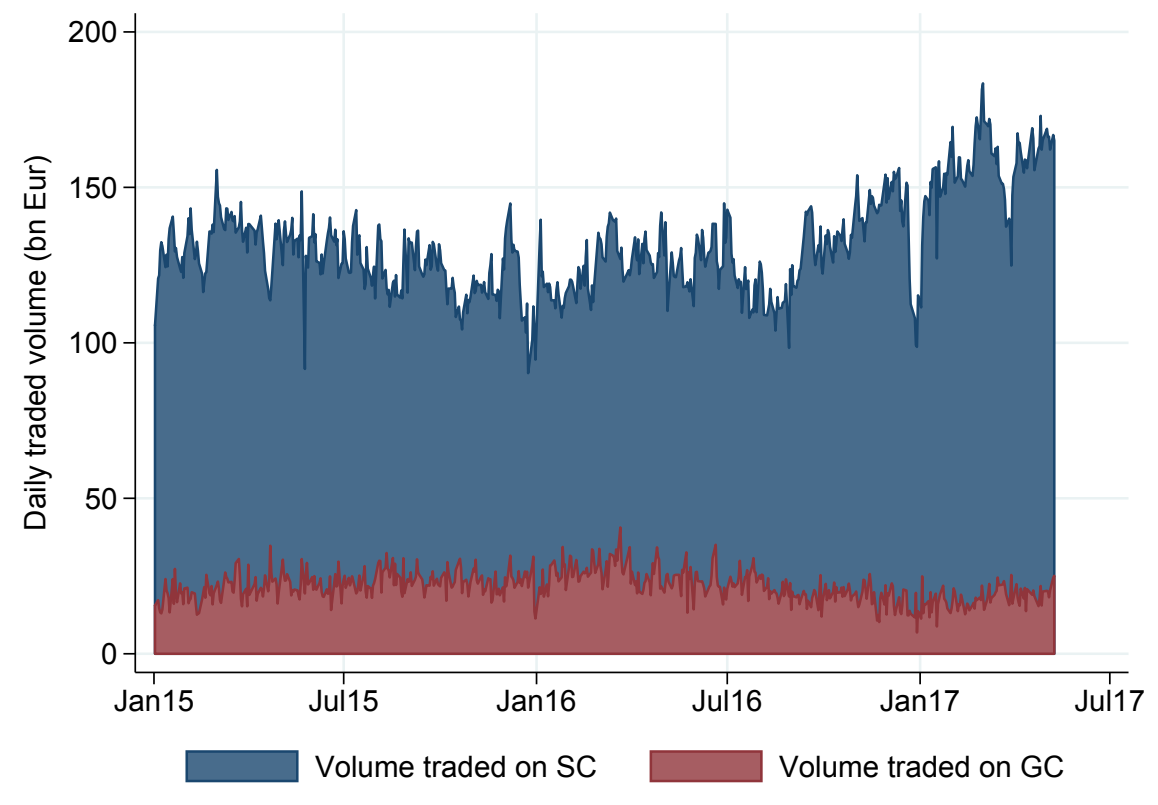

Source: Brokertec, Euro area collateral.

On average, around 170 bn EUR were exchanged each day on the period. For each transaction, we have the trade date, the term, the trade volume, the rate, and the collateral identified by a unique ISIN. We focus on the SC repo transactions of the seven largest Euro area economies ${ }^{21}$ and exclude bonds issued by supranationals and keep only securities issued by central governments. ${ }^{22}$ As the majority of transactions (67\%) has a maturity of one day and is settled two days after the trade (Spot Next), we also focus on this tenor.

As the highest frequency of our other data is daily, we compute for each security a daily

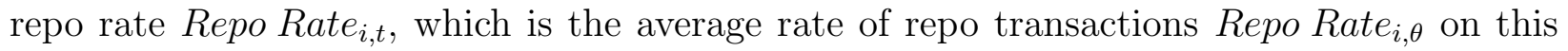
security at date $t$, weighted by volumes exchanged.

$$
\text { Repo Rate }_{i, t}=\left[\frac{\sum_{\theta=1}^{n} \text { Repo Rate }_{i, \theta} \times \text { Volumes }_{i, \theta}}{\sum_{t}^{n} \times \text { Volumes }_{i, t}}\right]_{t}
$$

Figure 8 shows the distribution of the $\mathrm{SC}$ repo rates at the bond-level by country, between January 2, 2015 and May 9, 2017.

\footnotetext{
${ }^{21}$ Germany (DE), France (FR), Italie (IT), Spain (ES), Netherlands (NL), Austria (AT), Belgium (BE)

${ }^{22}$ Securities issued by the German agency KFW or the French agency CADES are excluded.
} 
Unlike other studies (e.g. D'Amico et al. (2014) or Corradin and Maddaloni (2017)) we will not use the specialness premium, computed as the spread of SC repo rates against a GC rate. While most studies use this spread to measure the extent of the "specialness" we do not find it suitable in our case. Contrary to previous works that usually focus on a single debt market (e.g. the US, the Italian market, etc.), we are comparing seven different countries, which might have very different levels of GC rates. For instance, some platforms allow to trade a repo against a GC German bond. It is a repo secured by an unspecified German government bond. This GC rate might not be the same as a general collateral rate against an Italian collateral. It is likely that the rate varies depending inter alia on the credit risk associated with sovereign debt. A market participant willing to lend out its cash would probably not lend at the same rate knowing that he could get any German collateral or a bond issued by another country. In most of our specifications, we will control for the general level of interest rates through our time fixed effects and more specifically the levels in each countries, through the country-time fixed effect. Thus, having SC rates or spread between a GC and SC rates at the left hand side would not yield different results, as GC would be captured by the country-time fixed effects.

\subsection{Eurosystem's purchases and bonds characteristics}

For the Eurosystem purchase program, we use proprietary data of all PSPP transactions made by the Eurosystem, at the security-day level. For each PSPP transaction, we have the trade and settlement dates, the book value, the nominal amount, and the ISIN identifier. The same security might be purchased several times during a day. When this is the case we sum the purchases made during the day). Then, we compute the cumulative sum of PSPP transactions at each date, and the ratio of this cumulative purchases on the nominal outstanding of the bond (i.e. the share of this bond held by the Eurosystem under its PSPP program).

We use of the Securities Holdings Database (SHS) to compute for each bond the structure of its detention among institutional investors, to explore whether the holding structure correlates with specific patterns of collateral demand and specialness. A detailed description of the database is given by Fache Rousová and Rodríguez Caloca (2015). We are particularly interested in the detention by inelastic investors, unlikely to lend their bond holdings in the repo market. In the spirit of Koijen et al. (2017), we call inelastic investors: insurance companies and pension funds, households, non-financial corporations and governments. Elastic investors include banks, mutual funds and the foreign sector. As with the PSPP, we compute 
the share of the nominal outstanding amounts held by these two investors' groups.

For each security, we complement daily repo and daily PSPP purchases data with data on bond characteristics, retrieved either through the EADB database (Eurosystem's eligible assets database) or Bloomberg (nominal outstanding, issue and maturity dates, issuer rating, coupon rate...). We also retrieve from Bloomberg and the ECB macro variables such as daily excess liquidity, OIS rates, European stocks volatility index VSTOXX and the sovereign CDS.

\subsection{Panel description}

For each country, we remove the first and the last percentile of specialness rates to deal with outliers, and we drop the last week of December 2016 and the first week of January 2017 because of heightened volatility at year-end. The results are virtually unchanged when we include the outliers and observations from 23/12/2016 to 07/01/2017. The cleaned sample consists of 203,203 observations, for 823 individual securities. Our panel remains unbalanced, as all bonds do not necessarily trade on the repo market on each date.

Table 1 gives the main descriptive statistics of variable we use in our empirical exercises.

Table 1: Cleaned sample 2nd Jan 2015 - 9th May 2017

\begin{tabular}{lrrrrr}
\hline Variable & mean & $\min$ & $\max$ & sd & obs \\
\hline Repo rate (bps) & -40.48 & -153.79 & 10.00 & 20.42 & 203203 \\
Share held PSPP (\%) & 6 & 0 & 33 & 8 & 203203 \\
Time-to-maturity (yr) & 6.99 & 0.01 & 70.05 & 8.59 & 203203 \\
Nom. outstanding (bn Eur) & 14.52 & 0.00 & 43.19 & 8.26 & 203203 \\
Share held by inelastic investors & 0.21 & 0.00 & 0.90 & 0.17 & 199885 \\
ISIN-Daily volume in Repo (mn Eur) & 294 & 1.00 & 7571 & 453 & 203203 \\
Credit rating (1=AAA) & 2.96 & 1.00 & 8.00 & 2.64 & 203203 \\
\hline
\end{tabular}

Figure 8 shows the daily distribution of these repo rates by country.

\section{Empirical strategy}

\subsection{OLS specifications}

The aim of this paper is to understand the behavior of special repo rates in the Euro area. The left hand-side variable is therefore the SC repo rate for a bond (an isin code) on a given day, constructed from Brokertec, as explained in the previous section. Our main 
independent variable is purchases of bonds by the Eurosystem under the PSPP. For each bond, we construct a variable "PSPP", which is equal to the ratio of PSPP purchases to the total amount outstanding (taken from the ECB eligible asset database), both expressed in nominal values. If the Eurosystem has bought $20 \%$ of a given bond under the PSPP, "PSPP" is equal to 20 for this bond.

In line with the literature, we run our regressions in first differences to deal with the persistence of these variables. ${ }^{23}$

We include bond fixed effects, which capture inter alia the original maturity of the bond, its coupon rate, whether it is inflation linked, and so on. We also include country-maturity bucket-time fixed effects, which capture macro variables (e.g. the amount of excess liquidity), the information about the issuer (e.g. credit rating), and possibly effects related to maturity buckets in this country (crucially haircuts as discussed above). To account for the possibility that error terms might be correlated across similar bonds in terms of maturity or country of issuance, we cluster our standard errors at the maturity-issuer level.

Our baseline OLS regressions is as follows:

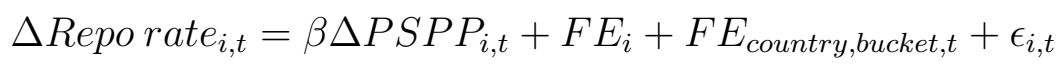

As in D'Amico et al. (2014), we allow for different types of bonds to be impacted differently by PSPP purchases. It is well known for instance that "on-the-run" bonds (the last issued bond of a given maturity in a given country) is in high demand from a certain number of investors and heavily sold short (see for instance Duffie (1996), Fisher (2002), D'Amico et al. (2014)). As a result, repo rates for on-the-run governments bonds might be lower in level (this effect cannot appear in first differentiated regressions) and the sensitivity of repo rates for on-the-run treasuries to PSPP purchases might be larger. We therefore construct a dummy variable equal to one whenever a security is on the run in a given country and equal to 0 otherwise. Symmetrically, we construct a variable "off-the-run" equal to one minus "on-the-run". Then we interact these dummy variables with the "PSPP purchases". This regression becomes:

$$
\begin{aligned}
\Delta \text { Repo }_{\text {rate }}^{i, t}=\beta_{1} \text { on-the-run } * \Delta P S P P_{i, t}+\beta_{2} \text { off-the-run } & * \Delta P S P P_{i, t} \\
& +F E_{i}+F E_{\text {country }, \text { bucket }, t}+\epsilon_{i, t}
\end{aligned}
$$

\footnotetext{
${ }^{23}$ As explained by D'Amico et al. (2014), taking first differences also reduces concern of serial correlation. We nevertheless performed tests of serial correlation as an additional check.
} 
Similarly, we construct a dummy variable equal to one when the bond is the "cheapest-todeliver" (ctd) and equal to 0 otherwise. ${ }^{24}$ We also interact these dummy variables with the first difference of "PSPP", the percentage of a given bond issue bought by the Eurosystem. We run other regressions with interactions. We notably look at the proportion of bonds held by "inelastic investors". These are investors we suspect to be relatively inelastic to changes the repo market. At last, we interact our measure of asset purchases with country dummies (to explore the potential heterogeneous effects of the PSPP for each country).

Another set of regressions intends to identify the effect of time varying characteristics common to all bonds. We therefore remove the time or country-time fixed effects and replace them with macro variables, such as excess liquidity, EONIA swaps, the VSTOXX, CDS spreads, etc. We then run regressions of the following form:

$$
\begin{aligned}
\Delta{\text { Repo } \text { rate }_{i, t}} & =\beta_{1} \Delta P S P P_{i, t}+\beta_{2} \text { Excess liquidity }_{t}+\beta_{3} O I S_{t} \\
& +\beta_{4} \operatorname{VSTOX} X_{t}+\beta_{5} C D S s_{t}+\beta_{6} S L F \text { vs cash }+\beta_{7} \text { End }_{m, q}+F E_{i}+\epsilon_{i, t}
\end{aligned}
$$

The SLF vs cash dummy captures the period of implementation of the Securities lending facility against cash. From Dec 15th 2016, under this facility, the Eurosystem lent part of the securities purchased as part of the PSPP against cash (limited to a total usage by counterparties at 50 bn Eur). ${ }^{25} \quad E n d_{m, q}$ is a dummy taking one at accounting reporting dates, namely end of month and end of quarter that are responsible of spikes in the repo rates times series. While this is not the core subject of this paper, Annex A provides some details on how regulations may be related to these calendar dates volatility.

\subsection{Addressing potential reverse causality}

The OLS regressions presented above are standard in the empirical literature on specialness. They are also useful because they provide us with a lower bound of the effect of the PSPP on repo rates. However, we suspect that they could be subject to an endogeneity bias and more specifically to reverse causality. Such bias would underestimate the effect of the PSPP on repo rates. ECB official statements confirm that PSPP purchases may take into account

\footnotetext{
${ }^{24} \mathrm{An}$ agent having sold a future contract on the " 5 -year German bond" has the possibility to deliver several bonds, at the contract maturity date. The "cheapest-to-deliver" is, among the bonds allowed for delivery, the bond which offers the highest return for someone having sold the future contract. It is therefore in high demand on the repo market. Traders borrow it, in order to deliver it see Buraschi and Menini (2002). We expect this type of bonds to have a less elastic supply and thus to be affected more heavily by PSPP purchases.

${ }^{25}$ Details can be found here: https://www.ecb.europa.eu/mopo/implement/omt/lending/html/index.en.html
} 
specialness. For instance, ECB board member Benoit Coeuré declared:

"One key principle underlying the implementation of the PSPP is [...] market neutrality of our operations. [...] To this end, we will take particular care to avoid exacerbating any existing market frictions. More specifically, we will try to avoid, to the extent possible, purchasing specific securities such as current cheapest-to-deliver bonds underlying futures contracts, securities commanding special rates in the repo market as a sign of temporary scarcity, and other assets displaying significant liquidity shortages." 26

In order to deal with this endogeneity concern, we propose a new instrumental variable. We take advantage of the legal and technical rules that the Eurosystem imposes on the PSPP purchases. In particular, we make use of three rules.

Rule 1: the Eurosystem may not buy bonds below a certain residual maturity. This minimum maturity was fixed at two years initially (ECB (2015c)) and at one year subsequently, from January 2017 onwards (ECB (2017a))

Rule 2: the Eurosystem may not buy bonds that have a residual maturity greater than 30 years (ECB (2015c)).

Rule 3: the Eurosystem may not buy bonds around their issuance or re-issuance dates. It also refrains from buying bonds of similar residual maturity. This rule intends to avoid any monetary financing of the government. ${ }^{27}$ The ECB Governing Council states that it applies "a "blackout period", i.e. a period during which securities could not be bought, was considered to be a safeguard to preserve the distinction between the primary and the secondary markets. It would also be applied for the neighboring securities along the yield curve. Such a provision would be in line with earlier practice to ensure compliance with the monetary financing prohibition laid down in the Treaty." ECB (2015a)

It is important to note that these rules were put in place before the start of the program,

26 "Embarking on public sector asset purchases" Speech by Benoit Coeuré, Member of the Executive Board of the ECB, at the Second International Conference on Sovereign Bond Markets, Frankfurt, 10 March 2015

${ }^{27}$ The Eurosystem considers that buying on the secondary market a bond just before or just after it is issued is equivalent to buying it on the primary market, something which is prohibited by the Lisbon Treaty, and before it by the Maastricht Treaty. 
and before specialness became so prevalent in the Euro area bond market. They were therefore put in place for reasons unrelated to the repo market and are a convenient source of exogenous variations in the amount of securities bought by the PSPP.

Combining these rules allows us to predict that a bond will not be purchased if affected by the blackout period, or if they are outside the eligible maturity.

To identify the "black-out period", we retrieve every issuance and re-issuance events in the European government bonds market. We define the bonds affected by "black-out periods" and its time frame similarly to De Santis and Holm-Hadulla (2017), although we use it in a different way to build our instrument. To ensure that our instrument affects repo rates only through PSPP purchases and satisfies the exclusion restriction, we use only the "black-out period" for "the neighboring securities along the yield curve". We do not use the "black-out period" for the securities that have directly been (re)-issued. This is because securities typically become more special in the repo market around their own (re)-issuance dates. This is well described for instance by D'Amico et al. (2014).

The first stage predicts $\widehat{P S P P}_{i t}$, based on the instrument "Eligible ${ }_{i, t}$ " that takes the value one whenever the three eligibility rules above are satisfied, and 0 otherwise. The first stage writes:

$$
\widehat{P S P P}_{i t}=\beta_{1} \text { Eligible }_{i t}+F E_{i}+F E_{\text {country }, \text { bucket }, t}+\epsilon_{i t}
$$

\section{Results}

Our results clearly confirm the effect of the PSPP on repo rates. Table 4 displays our baseline OLS regressions, showing the effect of PSPP purchases (as a share of the outstanding amount) with different set of fixed effects. As expected, coefficients are negative and strongly significant. It implies that the higher the amount purchased by the Eurosystem of a given bond on a given day (scaled by the total amount outstanding), the lower the rate of this bond on the repo market. The magnitude and significance of coefficients is little affected by the inclusion of fixed effects. Looking at the third column of table 4, one can see that buying $1 \%$ of the total outstanding (that would represent on average 150 million), would result in a decrease of 0.78 basis points of repo rates. The economic importance of the effect is line with the literature. It is above the estimates found for the US market by D'Amico et al. (2014) and below those of Corradin and Maddaloni (2017) for the Italian repo market. ${ }^{28}$

\footnotetext{
${ }^{28}$ These differences could be related to the securities lending program of the central banks when they conduct the purchases, as discussed in section 6 .
} 
It is very likely that the effect of bond purchases on repo rates is heterogeneous depending on the characteristics of the bond. Therefore, we allow for these heterogeneous effects to show up by interacting the variable "PSPP" with different dummy variables. The second column of table 5 shows the effect of PSPP purchases on "on-the-run securities" (most recently issued) vs. "off-the-run securities". As predicted by theory, "on-the-run" securities are more affected by central bank assets purchases than other securities, being also the most liquid and therefore most likely to be sold short Duffie (1996). The effect is around twice as large, in line with the estimates of D'Amico et al. (2014) for the US market for on-the-run vs. off-the run securities. Similarly, looking at the third column of 5, one can see that the so called "cheapest-to-deliver" securities (which are usually more heavily short-sold than other other securities) are once again more affected by the PSPP than other securities. ${ }^{29}$ In the fourth column, we explore the effect of the PSPP depending on the type of investors holding the bond. In line with theory we find that bonds held by investors relatively inelastic to repo market conditions (such as pension funds, households, non-financial corporations and governments) are more sensitive to asset purchases. Purchasing $1 \%$ of the outstanding amount leads to a decline of 1.8 basis point for a bond which is wholly held by inelastic investors. This is due to the fact that those investors will not arbitrage the specialness premium when it starts to rise. At the other extreme, purchasing $1 \%$ of the outstanding amount of a bond held completely by "elastic investors" leads to a decline of only 0.48 basis points. One interpretation of this result is related to differentiated effects of PSPP purchases when the purchased bond is held in inventories by the direct counterparties of the central bank (i.e. banks), as opposed to the case when the counterparties do not hold the bond. Let's assume the purchased bond is held by inelastic investors (i.e. insurance companies, for instance). In this case, the purchased bond may be delivered to the central bank by its regular bank counterparty through a short-sale, then covered in the SC repo market.

We also look at the heterogeneous effects across countries, using interactions with country dummies. As one can see from the last column of table 5 , the magnitude of the effect differs markedly between the different countries. The most affected countries are in order: Spain, Italy and Germany. ${ }^{30}$ In Spain and Italy, purchasing $1 \%$ of the outstanding amount would

\footnotetext{
${ }^{29}$ Strictly speaking, one should add the dummy variables "on-the-run" and "cheapest-to-deliver" separately from their interaction terms. In practice, the dummies are not significant and do not change the results. Skipping them allow to lighten the table. Results including them are available upon request. This problem does not arise in the last two columns of table 5, because the variable original maturity and the country dummy variables without interactions are already contained in the bond fixed effects.

${ }^{30}$ Interestingly, our estimates point to a smaller effect in absolute value for Italy than Corradin and Maddaloni (2017) who find that purchasing $1 \%$ of the outstanding leads to a decline of 5 bps. This could be
} 
result in a decrease in repo rates greater than 1 basis point. Theoretically, this difference could be explained for instance by the fact that these three countries have securities lending program that are more penalizing than others (as discussed in section 6).

To isolate time-varying factors that can affect repo rates, we remove time fixed-effects. Results are shown in table 6. The first column recalls our benchmark regression with bond and country-time fixed effects. The following three columns run regressions with time varying variables, with different set of fixed effects (but no time fixed effects). The results indicate that excess liquidity has a negative effect on repo rates. For 1 additional billion euro of excess liquidity, the $\mathrm{SC}$ repo rate for any given bond declines by $0.022 \mathrm{bps}$. It implies that for 1,000 billion euro of excess liquidity created through asset purchases, the average effect on SC rates would account for -22 basis points. This could be due to the fact that PSPP places some cash in the hands of agents which are not banks, without access to the DFR. Those agents, by construction, then need to deposit this cash with a bank which has an account with the Eurosystem. As explained in Section 2, this redistribution of cash toward non-banks could lead to some competition issues that could depress money market rates. The purchases of some bonds may also affect the price of other non-purchased bonds, which we may capture with this variable.

Interestingly, excess liquidity created through MRO (main refinancing operations) and LTRO (longer-term refinancing operations) seems to also depress repo rates. When LTROs and MROs increase, so does the amount of collateral that banks pledge to the Eurosystem. This leads banks to withdraw collateral (including government bonds) from the stock of collateral available for lending and thus lowers supply on the SC repo market. ${ }^{31}$

Both end of month and end of quarter dummies' coefficients are negative and highly significant. This might reflect window dressing by financial institutions, in particular from banks, around accounting and regulatory reporting dates. First, financial institutions might be willing to hold high-quality liquid assets (HQLA) on their balance sheet to improve their regulatory ratios such as the LCR. In order to hold these bonds, they avoid lending them during reporting dates, hence reducing the supply of bonds on the SC repo market. In Duffie's model specialness arises precisely because some agents are unwilling to lend their bonds. Figure 6 suggests that these dynamics might have been at play at least at year-ends, noticeable in the daily volumes exchanged on the SC market. Second, banks have incentives due to the fact that no securities lending program was available during their sample period. They also look at period of heightened market stress, were central bank purchases could have additional signaling effect, compared to our sample period.

${ }^{31}$ Banks have to provide collateral as a guarantee to borrow from the Eurosystem. 
to deleverage before having to report the size of their end-of-period balance sheet. Lending securities on the SC market or intermediating such lending, increases leverage (banks have to borrow cash in any case when they engage in such an activity).

Annex A provides details about each kind of regulatory constraints. In particular, calendar-dates effects can be related to window dressing around LCR and leverage ratio reporting dates.

We control for possible seasonnality patterns with month and day variables, the first being the number of the month (1-12) and the second the number of the day (1-31), and also for the last day of the ECB maintenance period.

The "SLF vs cash" dummy corresponding to the period of implementation of the facility against cash collateral (from 15th dec 2016) is associated with alleviated pressure on the repo market, consistent with theory. Yet it should be stressed that this period might also see other changes that we have not identified. Thus, the interpretation of the coefficient should be particularly prudent.

In Table 7, we estimate the same specification for bonds by percentiles of their SC repo rates, to assess if the independent variables have the same effect across the whole distribution of SC repo rates. We show the results for the p5, p25, p25-50, p50-75, p75 and 95p percentiles, with the p5 being the percentile formed by the bonds trading at the lowest $\mathrm{SC}$ repo rates, i.e. with the largest specialness premia. Interestingly, our results suggest that the PSPP has a stronger effect on the bottom of the distribution: for the $5 \%$ bonds that trade at the lowest repo rates (with the highest specialness premia) purchasing $1 \%$ of their outstanding amount is associated with a decline of about $2 \mathrm{bps}$. They also seem to be more sensitive to end-of-month and to seasonality. For the top of the distribution (bonds that trade with the lowest specialness premia), PSPP appears to be less (or not) statistically significant.

We then turn to our regressions that use our instrument. We run the same regressions as in table 4, now using a 2SLS procedure, where we instrument $\triangle P S P P_{i, t}$ with Eligible $e_{i, t}$. As expected, the effect of central banks' asset purchases are now estimated to be much larger. After controlling for fixed-effects, column 4 of table 8, indicates that purchases of $1 \%$ of the amount of bond outstanding by the central bank decreases repo rate by about 5 bps, compared to 0.78 estimated previously. This result underscore the importance of our instrument: once endogeneity is properly accounted for, the effect of the PSPP on the repo market is more than sixfold.

We also examine the first stage of our 2SLS regression, and run several tests. First, we confirm that in the first stage, the coefficient associated with Eligible $_{i, t}$ (first column of 8) 
is positive and significant as one would expect. Second, we look at the F statistic (equal to 170), to make sure it is above the level suggested by the rule of thumb (10). We also checked the Stock-Yogo critical values and the Kleibergen test, all dissipating any weak instrument concerns.

We also run several robustness checks, to ensure our results are not driven by a particular time frame or by our procedure to eliminate outliers. We exclude for instance the first semester of 2015, on the account that the program only starts in March and that money market rates are rather volatile during this period. We run our baseline regressions on subsamples eg. the period of late 2016 early 2017. Our results remain little affected by these changes.

\section{Implications for monetary policy}

Our results suggest that the PSPP has depressed repo rates by intensifying the scarcity of bonds and by increasing the amount of excess liquidity. Both effects raise a number of monetary policy issues.

\subsection{Should specialness per se be a concern at all?}

When discussing normative considerations around specialness, several factors need to be taken into account.

First, GC rates are seen as reflecting the price of liquidity and their deviation from monetary policy-controlled rates might at least pose communication issues. We found that in fact GC rates might still embed general preferences about country-specific collateral and different response to excess liquidity. GC rates behave like the upper envelope of all SC rates (see section 2.2), because in a GC transaction, a rational agent will always deliver the collateral that has the lowest value in the SC market. Thus, when specialness is extremely prevalent, GC rates cannot be considered as pure risk-free rates. A direct implication is on the monetary policy pass-through to money market rates. An increase of the DFR may not necessarily be transmitted one-for-one to repo rates. In a sense, the deviation between market rate and the policy rate signals a potential trade-off between steering short interest rates and being able to control long term yields (via assets purchase programs).

Second, repo rates have implications for bond yields. Empirical works by Jordan and Jordan (1997), Fontaine and Garcia (2012) and D'Amico et al. (2014) confirm this relationship in the case of US treasury market. This suggests that central bank purchases may affect 
bond yields through through the repo market. The existence of a relationship between repo rates and bond yields $\mathrm{m}$ also affect the transmission of monetary policy rate to the yield curve. It may reduce the monetary policy passthrough. This occurs not only at the short end of the yield curve but also at the long end, as long as scarcity prevails. For instance, Pelizzon et al. (2018) also show how scarcity distorts the price of other types of instruments such as futures contracts.

Third, specialness reflects the presence of market frictions, namely a demand for specific bonds (a form of imperfect substituability) and imperfect arbitrage. To the extent that the PSPP reinforces bond scarcity, it means that it imposes a greater cost on those who need to borrow them. For instance, if banks borrow the bonds to fulfill their regulatory obligations (or are not allowed to lend them out), they forgo the difference between the repo rate and the deposit facility rate. The distributional effects of these costs and their impact on welfare remains unclear but would be an interesting venue for further research.

\subsection{What can central banks do about the low level of repo rates?}

The previous subsection has identified possible problems associated with the current level of repo rates. Central banks have instruments, if needed, to offset each of them.

In principle, a purely liquidity-driven rate should not trade below the DFR. Market participants should always prefer to deposit their cash into an account with the safest counterparty (the central bank). However, because some market participants do not have access to the central bank, imperfect competition and lack of arbitrage in the money market may result in rates below the DFR. If this is the case, central banks may adjust their operational framework to include instruments accessible to non-banks, as was done in the US with overnight reverse repo facility that is opened to mutual funds, for instance (Frost et al. (2015)). Alternatively, we suggest that some country-specific GC rates are currently not completely liquidity-driven, when all bonds from a given country trade on special. In that case, GC rates may simply reflect the lowest SC rates of specific bonds that are relatively less in demand in the SC repo market.

This suggests that besides liquidity management, frictions associated with bond scarcity could be alleviated by the central bank to improve the monetary policy transmission. The theoretical literature supports the idea of lending bonds acquired by the central bank through a securities lending facility. Figure 7 represents the impact of the introduction of the SLF in the SC repo market of a given security, when such a SLF offers bonds for a minimum spread against GC (here, 10 bps). 
Figure 7: Impact of the introduction of the SLF on the SC repo market

quantity available in

the repo market (incl. SLF)

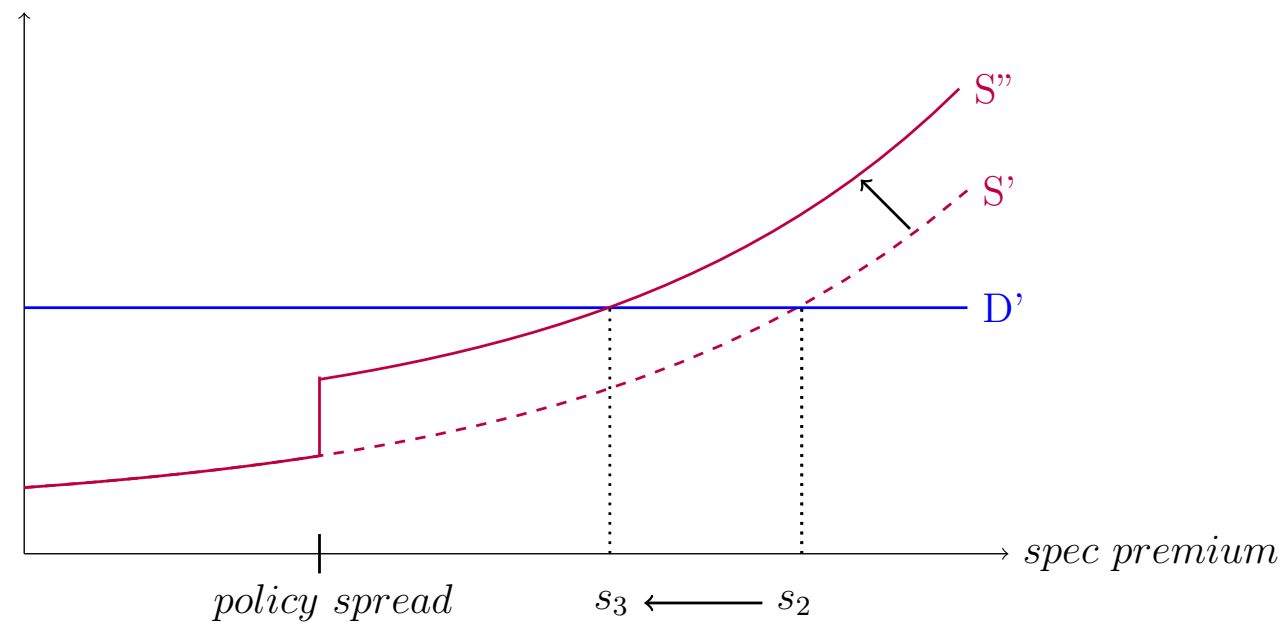

Note: we illustrate the impact of the introduction of a securities lending facility (SLF). Above a given "policy rate" announced by the central bank, which corresponds to a level of specialness premium, bonds are lent at the SLF against GC - or less special - collateral. This shifts upward the supply curve in an hypothetical repo market constituted of the private repo and SLF. As a consequence, after its introduction, the specialness premium at equilibrium decreases from $s_{2}$ to $s_{3}$. This result is in line with the theoretical framework built by Duffie and Krishnamurthy (2016) on the US money market. In practice, in the SLF (against securities as collateral) of some euro area central banks (Germany, France, Netherlands for instance), any monetary policy counterparty can borrow the security at the central bank against a GC security, for a quantity not above 200 mln EUR, at a "policy spread" that is at least equal to 10 bps below the GC rate. 
Table 2: Securities lending facilities (SLF) against security conditions

\begin{tabular}{lll}
\hline Country & SLF cost, to borrow a specific security & Limits \\
\hline Germany & GC rate minus some fixed (confidential) spread & $200 \mathrm{mln}$ EUR/security \\
Netherlands & GC rate minus 10 to 25 basis points & $200 \mathrm{mln}$ EUR/security \\
France & GC rate minus 10 to $25 \mathrm{bps}$ & $200 \mathrm{mln}$ EUR/security \\
Italy & $\begin{array}{l}\text { The special repo rate for that security minus an } \\
\text { additional penalty of } 10 \text { basis points }\end{array}$ & \\
Spain & $\begin{array}{l}\text { The most penalizing of these two rates: special } \\
\text { repo market rate for that security or the GC rate }\end{array}$ & \\
& minus 10 basis point & \\
\hline US & Minimum bid rate of 5 basis points & $90 \%$ limit on holdings \\
\hline
\end{tabular}

Our empirical results suggest that the period of implementation of the SLF against cash was associated with lower pressure on the special repo market, in spite of its limited size. This is likely to be the case thanks to the more attractive pricing of the SLF against cash facility (See table 2). In countries where all bonds have value in the SC repo market, borrowing bonds against cash is also more advantageous than borrowing a scarce bond using another scarce bond.

There are therefore arguments supporting a larger securities lending facility. In theory specialness remains only because some agents are not willing to lend out the securities they hold. So far, Euro area national central banks manage their securities lending on a decentralized basis. Each national central bank has different conventions with some of them being much penalizing than others.

In the US, specialness has been much less prevalent (Fleming et al. (2010) and D'Amico et al. (2014)). One reason for this might be related to the attractive pricing of securities lending programs of the New York Fed. The overnight securities lending facility offers specific securities against any general collateral at a fee as low as 4.9 basis points ${ }^{32}$. In contrast, some central banks of the Eurosystem lend specific securities way below market rate (i.e. on more expensive terms), as described on table 2.

\footnotetext{
${ }^{32}$ Michael Fleming, Frank Keane, Jake Schurmeier, and Emma Weiss, "A Closer Look at the Federal Reserve's Securities Lending Program," Federal Reserve Bank of New York Liberty Street Economics (blog), August 17, 2016, http://libertystreeteconomics.newyorkfed.org/2016/08/ a-closer-look-at-the-federal-reserves-securities-lending-program.html
} 
Table 3: Securities lending facilities (SLF) against cash conditions

\begin{tabular}{lll}
\hline Country & SLF cost, to borrow a specific security against cash & Limits \\
\hline Eurosystem & -30 basis points below the ECB deposit facility rate & 50bn EUR in total \\
\hline Source: central banks' respective websites
\end{tabular}

\section{Conclusion}

This paper demonstrates the links between the Eurosystem PSPP and the low level of repo rates in the Euro area since 2015. We found the PSPP contributes to depressing repo rates both by increasing the scarcity of the bonds purchased and through more aggregated effects by increasing the amount of excess liquidity. Increased dispersion of repo rates below the central bank remuneration of reserves might be challenging going forward. Not only the control over short term interbank rates may be more difficult, but it also raises the question of the transmission of monetary policy to bond yields and asset prices. Central banks, however, have instruments that could be used to mitigate such kind of distortions. Finally, our study sheds light on the possibility that central bank purchases are accommodated by short sales and covered in the repo market in the first place, contributing to a better understanding of the mechanisms behind asset purchases programs. 
Figure 8: Distribution of SC repo rates by bond and by country

We exclude the last week of December 2016 and the first week of January 2017 to exclude year-end volatility. Each point represents the daily volume-weighted rate traded on the Repo special market and on a unique special bond.
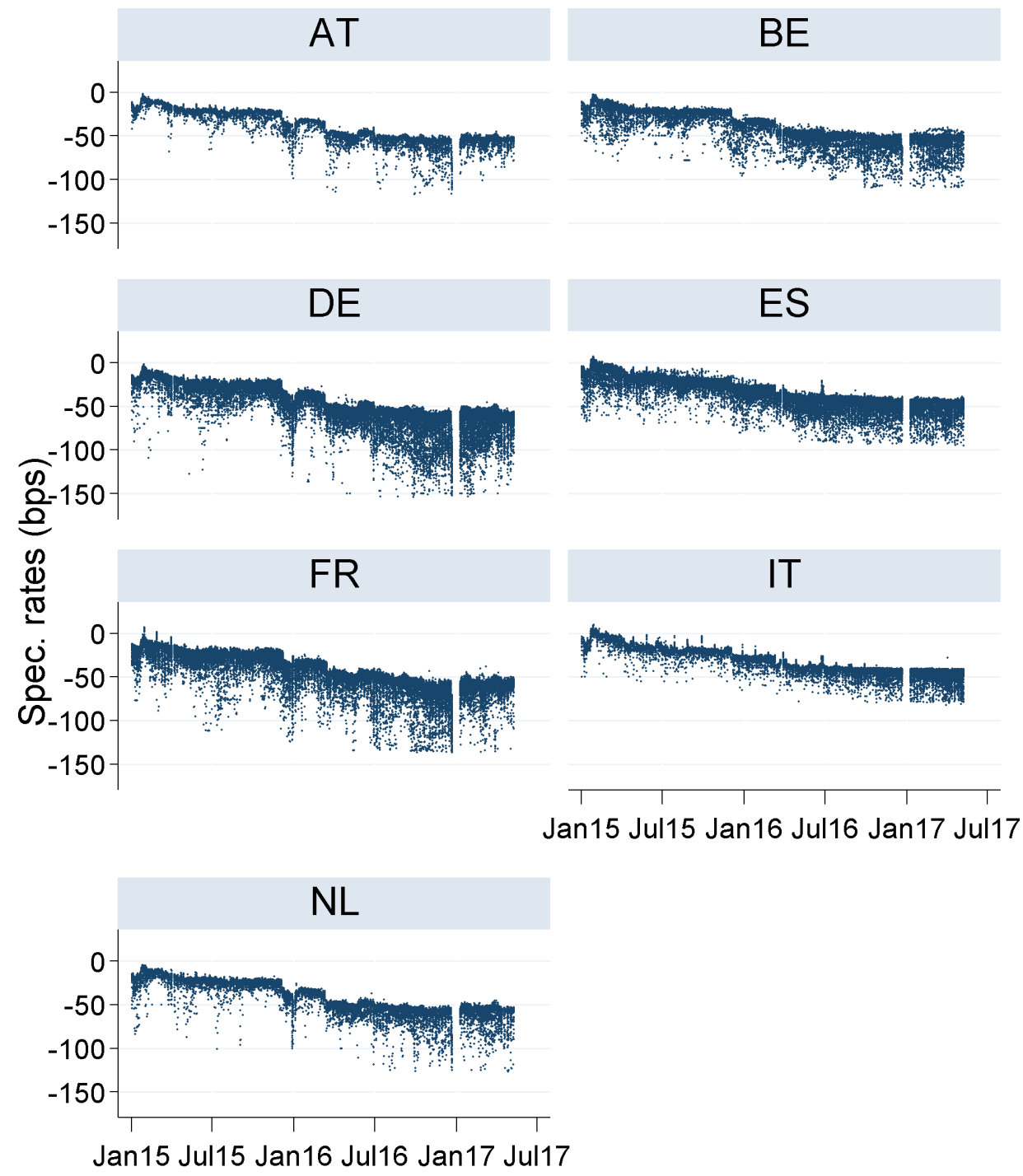


\section{Tables}

Table 4: Effect of PSPP purchases on SC repo rates

This table shows the impact of PSPP purchases on SC repo rates. PSPP variable is the variation of the share of the bond outstanding held by the PSPP. We use various set of fixed effects: bond fixed effects, and a 'country-bucket-time' fixed effect that captures common trend for a given date in a given country for similar maturities. The number of observations may change due to singletons. Standard errors are clustered at the maturity bucket-country level.

\begin{tabular}{lccc}
\hline \hline & $(1)$ & $(2)$ & $(3)$ \\
& SC repo rate & SC repo rate & SC repo rate \\
\hline PSPP & $-0.656^{* * *}$ & $-0.765^{* * *}$ & $-0.781^{* * *}$ \\
& $(0.112)$ & $(0.0914)$ & $(0.0961)$ \\
Bond FE & Yes & No & Yes \\
Country-Bucket-Time FE & No & Yes & Yes \\
\hline$R^{2}$ & 0.004 & 0.509 & 0.512 \\
Observations & 202323 & 201864 & 201855 \\
\hline \hline
\end{tabular}

Standard errors in parentheses

${ }^{*} p<0.10,{ }^{* *} p<0.05,{ }^{* * *} p<0.01$ 
Table 5: Effect of PSPP purchases on SC repo rates, differentiated effects

In this table we use various interactions terms to account for possible heterogeneous marginal effects. PSPP variable is the share of the bond outstanding held by the PSPP. Inelastic and elastic refer to the share of each security held by specific types of investors.

\begin{tabular}{|c|c|c|c|c|c|}
\hline & $\begin{array}{c}(1) \\
\text { SC repo rate }\end{array}$ & $\begin{array}{c}(2) \\
\text { SC repo rate }\end{array}$ & $\begin{array}{c}(3) \\
\text { SC repo rate }\end{array}$ & $\begin{array}{c}(4) \\
\text { SC repo rate }\end{array}$ & $\begin{array}{c}(5) \\
\text { SC repo rate }\end{array}$ \\
\hline PSPP & $\begin{array}{c}-0.781^{* * *} \\
(0.0961)\end{array}$ & & & & \\
\hline PSPP $x$ on-the-run dummy & & $\begin{array}{c}-1.163^{* * *} \\
(0.173)\end{array}$ & & & \\
\hline PSPP x off-the-run & & $\begin{array}{c}-0.583^{* * *} \\
(0.101)\end{array}$ & & & \\
\hline PSPP x cheapest-to-deliver & & & $\begin{array}{c}-1.407^{* * *} \\
(0.526)\end{array}$ & & \\
\hline PSPP x not-ctd & & & $\begin{array}{c}-0.776^{* * *} \\
(0.0967)\end{array}$ & & \\
\hline PSPP Inelastic & & & & $\begin{array}{c}-1.778^{* * *} \\
(0.602)\end{array}$ & \\
\hline PSPP Elastic & & & & $\begin{array}{c}-0.476^{* * *} \\
(0.148)\end{array}$ & \\
\hline PSPP x DE & & & & & $\begin{array}{c}-0.961^{* * *} \\
(0.276)\end{array}$ \\
\hline PSPP x FR & & & & & $\begin{array}{c}-0.400^{* *} \\
(0.168)\end{array}$ \\
\hline PSPP x IT & & & & & $\begin{array}{c}-1.152^{* * *} \\
(0.302)\end{array}$ \\
\hline PSPP x ES & & & & & $\begin{array}{c}-1.233^{* * *} \\
(0.140)\end{array}$ \\
\hline PSPP x NL & & & & & $\begin{array}{c}-0.282^{* * *} \\
(0.0978)\end{array}$ \\
\hline PSPP x BE & & & & & $\begin{array}{c}-0.605^{* * *} \\
(0.212)\end{array}$ \\
\hline PSPP x AT & & & & & $\begin{array}{c}-0.476^{* *} \\
(0.241)\end{array}$ \\
\hline Bond FE & Yes & Yes & Yes & No & Yes \\
\hline Country-Bucket-Time FE & Yes & Yes & Yes & No & Yes \\
\hline$R^{2}$ & 0.512 & 0.512 & 0.512 & 0.504 & 0.512 \\
\hline Observations & 201855 & 201855 & 201855 & 198711 & 201855 \\
\hline
\end{tabular}

Standard errors in parentheses, clustered as the maturity-country level

${ }^{*} p<0.10,{ }^{* *} p<0.05,{ }^{* * *} p<0.01$

33 
Table 6: Effect of PSPP purchases and excess liquidity on SC repo rates

In this table, we remove fixed effects to capture the impact of time varying variables such as excess liquidity and the impact of end of periods. "SLF cash dummy" corresponds to the period of implementation of the securities lending against cash, ie. since 15th Dec 2016. PSPP variable is the share of the bond outstanding held by the PSPP.

\begin{tabular}{|c|c|c|c|}
\hline & $\begin{array}{c}(1) \\
\text { SC repo rate }\end{array}$ & $\begin{array}{c}(2) \\
\text { SC repo rate }\end{array}$ & $\begin{array}{c}(3) \\
\text { SC repo rate }\end{array}$ \\
\hline PSPP & $\begin{array}{c}-0.781^{* * *} \\
(0.0961)\end{array}$ & $\begin{array}{c}-0.554^{* * *} \\
(0.105)\end{array}$ & $\begin{array}{c}-0.549^{* * *} \\
(0.111)\end{array}$ \\
\hline Excess liquidity (excl. MRO and LTRO) & & $\begin{array}{c}-0.0219^{* * *} \\
(0.00266)\end{array}$ & $\begin{array}{c}-0.0218^{* * *} \\
(0.00267)\end{array}$ \\
\hline MRO and LTRO & & $\begin{array}{c}-0.0539^{* * *} \\
(0.00536)\end{array}$ & $\begin{array}{c}-0.0530^{* * *} \\
(0.00556)\end{array}$ \\
\hline GC Pooling & & $\begin{array}{l}0.644^{* * *} \\
(0.0336)\end{array}$ & $\begin{array}{l}0.642^{* * *} \\
(0.0342)\end{array}$ \\
\hline End-of-month & & $\begin{array}{c}-1.757^{* * *} \\
(0.421)\end{array}$ & $\begin{array}{c}-1.753^{* * *} \\
(0.423)\end{array}$ \\
\hline End-of-quarter & & $\begin{array}{c}-1.155^{* * *} \\
(0.350)\end{array}$ & $\begin{array}{c}-1.211^{* * *} \\
(0.350)\end{array}$ \\
\hline Last day of maintenance period & & $\begin{array}{l}0.00110^{* * *} \\
(0.000135)\end{array}$ & $\begin{array}{l}0.00102^{* * *} \\
(0.000113)\end{array}$ \\
\hline VSTOXX volatility & & $\begin{array}{c}-0.0201^{* * *} \\
(0.00212)\end{array}$ & $\begin{array}{c}-0.0167^{* * *} \\
(0.00208)\end{array}$ \\
\hline CDS France & & $\begin{array}{l}0.0313^{* * *} \\
(0.00958)\end{array}$ & $\begin{array}{l}0.0319^{* * *} \\
(0.00970)\end{array}$ \\
\hline CDS Italy & & $\begin{array}{l}-0.0106^{* *} \\
(0.00462)\end{array}$ & $\begin{array}{c}-0.0103^{* *} \\
(0.00423)\end{array}$ \\
\hline CDS Spain & & $\begin{array}{l}0.0518^{* * *} \\
(0.00418)\end{array}$ & $\begin{array}{l}0.0515^{* * *} \\
(0.00407)\end{array}$ \\
\hline Swap OIS 5-Year & & $\begin{array}{l}1.336^{* *} \\
(0.526)\end{array}$ & $\begin{array}{c}1.344^{* * *} \\
(0.513)\end{array}$ \\
\hline Month & & $\begin{array}{c}-0.0827^{* * *} \\
(0.00965)\end{array}$ & $\begin{array}{c}-0.0780^{* * *} \\
(0.00967)\end{array}$ \\
\hline Day & & $\begin{array}{l}0.0473^{* * *} \\
(0.00841)\end{array}$ & $\begin{array}{l}0.0475^{* * *} \\
(0.00851)\end{array}$ \\
\hline SLF cash dummy & & $\begin{array}{l}0.352^{* * *} \\
(0.0886)\end{array}$ & $\begin{array}{l}0.443^{* * *} \\
(0.0696)\end{array}$ \\
\hline Bond FE & Yes & No & Yes \\
\hline Country-Bucket-Time FE & Yes & No & No \\
\hline$R^{2}$ & 0.512 & 0.047 & 0.049 \\
\hline Observations & 201855 & 201600 & 201592 \\
\hline
\end{tabular}

Standard errors in parentheses, clustered as the maturity-country level

${ }^{*} p<0.10,{ }^{* *} p<0.05,{ }^{* * *} p<0.01$ 
Table 7: Effect of PSPP purchases and excess liquidity on SC repo rates by percentiles

In this table, we run the last specification of Table 6 for percentiles in SC repo rates. p5 is restricted to the $5 \%$ bonds that trade at the lower SC repo rates (ie. with the highest specialness premia), while p95 is restricted to the $5 \%$ of bonds that trade at the higher $\mathrm{SC}$ repo rates (with the smallest specialness premia).

\begin{tabular}{|c|c|c|c|c|c|c|}
\hline & $\begin{array}{l}(1) \\
\text { p5 }\end{array}$ & $\begin{array}{l}(2) \\
\text { p25 }\end{array}$ & $\begin{array}{c}(3) \\
\mathrm{p} 25-50\end{array}$ & $\begin{array}{c}(4) \\
\mathrm{p} 50-75\end{array}$ & $\begin{array}{l}(5) \\
\text { p75 }\end{array}$ & $\begin{array}{l}(6) \\
\text { p95 }\end{array}$ \\
\hline PSPP & $\begin{array}{c}-2.157^{* *} \\
(0.967)\end{array}$ & $\begin{array}{c}-1.873^{* * *} \\
(0.533)\end{array}$ & $\begin{array}{c}-0.548^{* * *} \\
(0.140)\end{array}$ & $\begin{array}{l}-0.111 \\
(0.216)\end{array}$ & $\begin{array}{c}-0.277^{* *} \\
(0.113)\end{array}$ & $\begin{array}{c}-0.372^{*} \\
(0.211)\end{array}$ \\
\hline $\begin{array}{l}\text { Excess liquidity } \\
\text { (excl. MRO and LTRO) }\end{array}$ & $\begin{array}{c}-0.0328^{* * *} \\
(0.0116)\end{array}$ & $\begin{array}{r}-0.0314^{* * *} \\
(0.00612)\end{array}$ & $\begin{array}{c}-0.0181^{* * *} \\
(0.00279)\end{array}$ & $\begin{array}{c}-0.0166^{* * *} \\
(0.00248)\end{array}$ & $\begin{array}{c}-0.0207^{* * *} \\
(0.00243)\end{array}$ & $\begin{array}{c}-0.0240^{* * *} \\
(0.00382)\end{array}$ \\
\hline MRO and LTRO & $\begin{array}{c}-0.0425^{* *} \\
(0.0197)\end{array}$ & $\begin{array}{c}-0.0451^{* * *} \\
(0.00830)\end{array}$ & $\begin{array}{c}-0.0557^{* * *} \\
(0.00411)\end{array}$ & $\begin{array}{c}-0.0409^{* * *} \\
(0.00540)\end{array}$ & $\begin{array}{c}-0.0671^{* * *} \\
(0.0179)\end{array}$ & $\begin{array}{c}-0.0694^{* * *} \\
(0.0227)\end{array}$ \\
\hline GC Pooling & $\begin{array}{l}0.611^{* * *} \\
(0.0987)\end{array}$ & $\begin{array}{l}0.654^{* * *} \\
(0.0750)\end{array}$ & $\begin{array}{l}0.684^{* * *} \\
(0.0505)\end{array}$ & $\begin{array}{l}0.612^{* * *} \\
(0.0573)\end{array}$ & $\begin{array}{l}0.609^{* * *} \\
(0.0886)\end{array}$ & $\begin{array}{l}0.574^{* * *} \\
(0.0906)\end{array}$ \\
\hline End-of-month & $\begin{array}{c}-3.776^{* * *} \\
(0.866)\end{array}$ & $\begin{array}{c}-2.592^{* * *} \\
(0.573)\end{array}$ & $\begin{array}{c}-2.117^{* * *} \\
(0.479)\end{array}$ & $\begin{array}{c}-1.354^{* * *} \\
(0.337)\end{array}$ & $\begin{array}{c}-0.888^{* *} \\
(0.368)\end{array}$ & $\begin{array}{c}-0.826^{* *} \\
(0.363)\end{array}$ \\
\hline End-of-quarter & $\begin{array}{l}1.431 \\
(2.630)\end{array}$ & $\begin{array}{l}-1.066 \\
(0.911)\end{array}$ & $\begin{array}{c}-0.984^{* *} \\
(0.424)\end{array}$ & $\begin{array}{c}-1.582^{* * *} \\
(0.359)\end{array}$ & $\begin{array}{c}-1.373^{* * *} \\
(0.331)\end{array}$ & $\begin{array}{l}-0.602 \\
(0.442)\end{array}$ \\
\hline $\begin{array}{l}\text { Last day of } \\
\text { maintenance period }\end{array}$ & $\begin{array}{c}0.00100 \\
(0.00147)\end{array}$ & $\begin{array}{l}0.00115^{* * *} \\
(0.000416)\end{array}$ & $\begin{array}{l}0.00117^{* * *} \\
(0.000172)\end{array}$ & $\begin{array}{c}0.000961^{* * *} \\
(0.000120)\end{array}$ & $\begin{array}{l}0.00111^{* * *} \\
(0.000141)\end{array}$ & $\begin{array}{c}0.000908^{* * *} \\
(0.000286)\end{array}$ \\
\hline VSTOXX volatility & $\begin{array}{l}-0.0146 \\
(0.0358)\end{array}$ & $\begin{array}{l}-0.0207^{* *} \\
(0.00928)\end{array}$ & $\begin{array}{c}-0.00962^{* *} \\
(0.00485)\end{array}$ & $\begin{array}{c}-0.0127^{* * *} \\
(0.00343)\end{array}$ & $\begin{array}{c}-0.0219^{* * *} \\
(0.00389)\end{array}$ & $\begin{array}{r}-0.0341^{* * *} \\
(0.00785)\end{array}$ \\
\hline CDS France & $\begin{array}{l}-0.0251 \\
(0.0774)\end{array}$ & $\begin{array}{c}0.0157 \\
(0.0309)\end{array}$ & $\begin{array}{l}0.0313^{* *} \\
(0.0133)\end{array}$ & $\begin{array}{l}0.0343^{* * *} \\
(0.00961)\end{array}$ & $\begin{array}{l}0.0433^{* * *} \\
(0.00978)\end{array}$ & $\begin{array}{c}0.0277 \\
(0.0176)\end{array}$ \\
\hline CDS Italy & $\begin{array}{c}0.0180 \\
(0.0262)\end{array}$ & $\begin{array}{r}-0.00231 \\
(0.0108)\end{array}$ & $\begin{array}{c}-0.00862 \\
(0.00585)\end{array}$ & $\begin{array}{c}-0.0135^{* * *} \\
(0.00428)\end{array}$ & $\begin{array}{c}-0.0147^{* * *} \\
(0.00385)\end{array}$ & $\begin{array}{c}-0.0171^{* *} \\
(0.00759)\end{array}$ \\
\hline CDS Spain & $\begin{array}{c}0.0180 \\
(0.0372)\end{array}$ & $\begin{array}{c}0.0507^{* * *} \\
(0.0125)\end{array}$ & $\begin{array}{c}0.0504^{* * *} \\
(0.0102)\end{array}$ & $\begin{array}{l}0.0496^{* * *} \\
(0.00717)\end{array}$ & $\begin{array}{l}0.0533^{* * *} \\
(0.00833)\end{array}$ & $\begin{array}{c}0.0623^{* * *} \\
(0.0142)\end{array}$ \\
\hline Swap OIS 5-Year & $\begin{array}{c}5.619 \\
(4.759)\end{array}$ & $\begin{array}{c}2.448 \\
(1.915)\end{array}$ & $\begin{array}{l}1.482^{* *} \\
(0.740)\end{array}$ & $\begin{array}{c}0.273 \\
(0.794)\end{array}$ & $\begin{array}{l}1.517^{* *} \\
(0.699)\end{array}$ & $\begin{array}{l}1.839^{*} \\
(0.996)\end{array}$ \\
\hline Month & $\begin{array}{c}-0.144^{* * *} \\
(0.0430)\end{array}$ & $\begin{array}{c}-0.163^{* * *} \\
(0.0244)\end{array}$ & $\begin{array}{c}-0.0994^{* * *} \\
(0.0101)\end{array}$ & $\begin{array}{c}-0.0521^{* * *} \\
(0.00958)\end{array}$ & $\begin{array}{c}-0.0398^{* * *} \\
(0.0127)\end{array}$ & $\begin{array}{c}-0.0352^{* *} \\
(0.0147)\end{array}$ \\
\hline Day & $\begin{array}{c}0.0321^{*} \\
(0.0188)\end{array}$ & $\begin{array}{c}0.0245^{* *} \\
(0.0110)\end{array}$ & $\begin{array}{c}0.0558^{* * *} \\
(0.0126)\end{array}$ & $\begin{array}{l}0.0537^{* * *} \\
(0.00808)\end{array}$ & $\begin{array}{c}0.0543^{* * *} \\
(0.0104)\end{array}$ & $\begin{array}{c}0.0528^{* * *} \\
(0.0117)\end{array}$ \\
\hline SLF cash dummy & $\begin{array}{c}1.380 \\
(1.192)\end{array}$ & $\begin{array}{c}0.121 \\
(0.259)\end{array}$ & $\begin{array}{l}0.332^{* *} \\
(0.164)\end{array}$ & $\begin{array}{c}0.598^{* * *} \\
(0.152)\end{array}$ & $\begin{array}{c}0.594^{* * *} \\
(0.140)\end{array}$ & $\begin{array}{l}0.600^{* *} \\
(0.291)\end{array}$ \\
\hline Bond FE & Yes & Yes & Yes & Yes & Yes & Yes \\
\hline $\begin{array}{l}R^{2} \\
\text { Observations }\end{array}$ & $\begin{array}{l}0.082 \\
11418\end{array}$ & $\begin{array}{l}0.041 \\
47932\end{array}$ & $\begin{array}{lc}35 & 0.101 \\
& 50677\end{array}$ & $\begin{array}{l}0.111 \\
49417\end{array}$ & $\begin{array}{l}0.118 \\
53407\end{array}$ & $\begin{array}{l}0.155 \\
13458\end{array}$ \\
\hline
\end{tabular}

Standard errors in parentheses, clustered as the maturity-country level

${ }^{*} p<0.10,{ }^{* *} p<0.05,{ }^{* * *} p<0.01$ 
Table 8: Effect of PSPP purchases on SC repo rates (IV)

This table shows the instrumented version of our baseline regression in table 4 . The Eligibility instrument is the interaction of a dummy that takes 1 if the bond is in an eligible maturity at date $t$ times a dummy that takes 1 if the bond is not affected (as a "neighbouring bond") by a blackout period. The first column shows the first stage, whether the other columns show the second stages introducing fixed effects.

\begin{tabular}{lcccc}
\hline \hline & $(1)$ & $(2)$ & $(3)$ & $(4)$ \\
& 1st stage & 2nd stage & 2nd stage & 2nd stage \\
\hline Eligibility & $0.0936^{* * *}$ & & & \\
& $(0.00713)$ & & & \\
$\widehat{P S P P}_{i t}$ & & & & \\
& & -0.130 & $-4.597^{* * *}$ & $-4.855^{* * *}$ \\
Country-Bucket-Time FE & Yes & No & Yes & Yes \\
Bond FE & & & & \\
\hline Adjusted $R^{2}$ & Yes & No & No & Yes \\
Observations & 0.106 & 0.000 & 0.448 & 0.448 \\
\hline \hline
\end{tabular}

Standard errors in parentheses, clustered at the maturity-country level.

${ }^{*} p<0.10,{ }^{* *} p<0.05,{ }^{* * *} p<0.01$

\section{References}

Adrian, T., Begalle, B., Copeland, A., and Martin, A. (2013). Repo and Securities Lending. In Risk Topography: Systemic Risk and Macro Modeling, NBER Chapters, pages 131-148. National Bureau of Economic Research, Inc.

Afonso, G. and Lagos, R. (2015). Trade Dynamics in the Market for Federal Funds. Econometrica, 83:263-313.

Armenter, R. and Lester, B. (2017). Excess Reserves and Monetary Policy Implementation. Review of Economic Dynamics, 23:212-235.

Arrata, W. and Nguyen, B. (2017). Price impact of bond supply shocks: Evidence from the eurosystem's asset purchase program. Banque de France Working Paper Series no. 623.

Baklanova, V., Caglio, C., Cipriani, M., and Copeland, A. (2016). The use of collateral in bilateral repurchase and securities lending agreements. Staff Reports 758, Federal Reserve Bank of New York. 
Bech, M. L. and Klee, E. (2011). The mechanics of a graceful exit: Interest on reserves and segmentation in the federal funds market. Journal of Monetary Economics, 58(5):415-431.

Bech, M. L. and Malkhozov, A. (2016). How have central banks implemented negative policy rates? BIS Quarterly Review.

Berentsen, A., Kraenzlin, S., and Müller, B. (2016). Exit strategies for monetary policy. ECON - Working Papers 241, Department of Economics - University of Zurich.

Boissel, C., Derrien, F., Örs, E., and Thesmar, D. (2014). Sovereign crises and bank financing: Evidence from the european repo market. Manuscript, HEC Paris.

Bottazzi, J.-M., Luque, J., and Páscoa, M. R. (2012). Securities market theory: Possession, repo and rehypothecation. Journal of Economic Theory, 147(2):477-500.

Bucalossi, A. and Scalia, A. (2016). Leverage ratio, central bank operations and repo market. Questioni di Economia e Finanza (Occasional Papers) 347, Bank of Italy, Economic Research and International Relations Area.

Buraschi, A. and Menini, D. (2002). Liquidity risk and specialness. Journal of Financial Economics, 64(2):243-284.

Carlson, M., Duygan-Bump, B., Natalucci, F., Nelson, B., Ochoa, M., Stein, J., and den Heuvel, S. V. (2016). The Demand for Short-Term, Safe Assets and Financial Stability: Some Evidence and Implications for Central Bank Policies. International Journal of Central Banking, 12(4):307-333.

Carpenter, S., Demiralp, S., Ihrig, J., and Klee, E. (2015). Analyzing federal reserve asset purchases: From whom does the fed buy? Journal of Banking 6 Finance, 52:230-244.

CGFS (2017). Repo market functioning. Technical report, Bank of International settlements.

Christensen, J. H. and Krogstrup, S. (2014). Transmission of Quantitative Easing: The Role of Central Bank Reserves. Working Paper Series 2014-18, Federal Reserve Bank of San Francisco.

Christensen, J. H. E., Lopez, J. A., and Shultz, P. (2017). Is There an On-the-Run Premium in TIPS? Working Paper Series 2017-10, Federal Reserve Bank of San Francisco. 
Coeuré, B. (2017a). Asset purchases, financial regulation and repo market activity. Speech by Benoit Cœuré, Member of the Executive Board of the ECB, at the ERCC General Meeting, Brussels, 14 November, $201 \%$.

Coeuré, B. (2017b). Bond scarcity and the ecb's asset purchase programme. Speech at the Club de Gestion Financiere d'Associes en Finance, Paris, 3 April 2017.

Corradin, S. and Maddaloni, A. (2017). The importance of being special: repo markets during the crisis. Working Paper Series 2065, European Central Bank.

D’Amico, S., Fan, R., and Kitsul, Y. (2014). The scarcity value of Treasury collateral: Repo market effects of security-specific supply and demand factors. Finance and Economics Discussion Series 2014-60, Board of Governors of the Federal Reserve System (U.S.).

De Santis, R. A. and Holm-Hadulla, F. (2017). Flow effects of central bank asset purchases on euro area sovereign bond yields: evidence from a natural experiment. Working Paper Series 2052, European Central Bank.

Duffie, D. (1996). Special repo rates. The Journal of Finance, 51(2):493-526.

Duffie, D. and Krishnamurthy, A. (2016). Passthrough efficiency in the fed's new monetary policy setting. In Designing Resilient Monetary Policy Frameworks for the Future. Federal Reserve Bank of Kansas City, Jackson Hole Symposium.

Dunne, P. G., Fleming, M. J., and Zholos, A. (2013). ECB monetary operations and the interbank repo market. Staff Reports 654, Federal Reserve Bank of New York.

ECB (2015a). Account of the monetary policy meeting governing council of the european central bank held in frankfurt am main on wednesday and thursday, 21-22 january 2015.

ECB (2015b). Decision (eu) 2015/1574 of the european central bank. Official Journal of the European Union.

ECB (2015c). Decision (eu) 2015/774 of the european central bank of 4 march 2015 on a secondary markets public sector asset purchase programme (ecb/2015/10). Official Journal of the European Union.

ECB (2015d). Money market survey 2015. 
ECB (2017a). Decision (eu) 2015/774 of the european central bank of 11 january 2017 amending decision (eu) 2015/774 on a secondary markets public sector asset purchase programme (ecb/2017/1). Technical report.

ECB (2017b). Recent developments in euro area repo markets, regulatory reforms and their impact on repo market functioning. Financial Stability Review November 2017 - Special features.

Ennis, H. M. and Keister, T. (2008). Understanding monetary policy implementation. Economic Quarterly, (Sum):235-263.

Fache Rousová, L. and Rodríguez Caloca, A. (2015). The use of securities holdings statistics (shs) for designing new euro area financial integration indicators. Technical report, Bank for International Settlements.

Faubert, V. and Sode, A. (2013). Are safe assets to become scarcer? Tresor Eco no 17 r.

Fernandez, R. (2017). European repo markets: Operating within a new normal. Technical report, Nomura European Rates Insights, 5 April 2017.

Ferrari, M., Guagliano, C., and Mazzacurati, J. (2016). Collateral scarcity premia in eu repo markets.

Fisher, M. (2002). Special repo rates: An introduction. Economic Review-Federal Reserve Bank of Atlanta, 87(2):27.

Fleming, M. J. and Garbade, K. D. (2004). Repurchase agreements with negative interest rates. Current Issues in Economics and Finance, 10(Apr).

Fleming, M. J., Hrung, W. B., and Keane, F. M. (2010). Repo Market Effects of the Term Securities Lending Facility. American Economic Review, 100(2):591-596.

Flodén, M. (2018). The riksbank's balance sheet: How large should it be in the future? Speech by Martin Flodén, Deputy Governor of the Sveriges Riksbank, at the Swedish House of Finance, 13 April, 2018.

Fontaine, J.-S. and Garcia, R. (2012). Bond Liquidity Premia. Review of Financial Studies, 25(4):1207-1254. 
Frost, J., Logan, L., Martin, A., McCabe, P. E., Natalucci, F. M., and Remache, J. (2015). Overnight RRP operations as a monetary policy tool: some design considerations. Staff Reports 712, Federal Reserve Bank of New York.

Fuhrer, L. M., Müller, B., and Steiner, L. (2017). The liquidity coverage ratio and security prices. Journal of Banking \& Finance, 75:292-311.

Garratt, R., Martin, A., McAndrews, J. J., and Nosal, E. (2015). Segregated balance accounts. Staff Reports 730, Federal Reserve Bank of New York.

Greenwood, R., Hanson, S. G., and Stein, J. C. (2015). A Comparative-Advantage Approach to Government Debt Maturity. Journal of Finance, 70(4):1683-1722.

Greenwood, R., Hanson, S. G., and Stein, J. C. (2016). The federal reserve's balance sheet as a financial-stability tool. In Designing Resilient Monetary Policy Frameworks for the Future," Jackson Hole Symposium: Federal Reserve Bank of Kansas City.

Huh, Y. and Infante, S. (2017). Bond Market Intermediation and the Role of Repo. Finance and Economics Discussion Series 2017-003, Board of Governors of the Federal Reserve System (US).

Jordan, B. D. and Jordan, S. D. (1997). Special repo rates: An empirical analysis. The Journal of Finance, 52(5):2051-2072.

Kandrac, J. and Schlusche, B. (2017). Quantitative Easing and Bank Risk Taking: Evidence from Lending. Finance and Economics Discussion Series 2017-125, Board of Governors of the Federal Reserve System (US).

Klee, E. C., Senyuz, Z., and Yoldas, E. (2016). Effects of Changing Monetary and Regulatory Policy on Overnight Money Markets. Finance and Economics Discussion Series 2016-084, Board of Governors of the Federal Reserve System (U.S.).

Koijen, R. S., Koulischer, F., Nguyen, B., Yogo, M., et al. (2017). Euro-area quantitative easing and portfolio rebalancing. American Economic Review, 107(5):621-627.

Kreicher, L. L., McCauley, R. N., and McGuire, P. (2013). The 2011 FDIC assessment on banks managed liabilities: interest rate and balance-sheet responses. BIS Working Papers 413, Bank for International Settlements. 
Krishnamurthy, A. (2002). The bond/old-bond spread. Journal of Financial Economics, 66(2-3):463-506.

Levels, A. and Capel, J. (2012). Is collateral becoming scarce? evidence for the euro area. Journal of Financial Market Infrastructures, 1(1):29-53.

Mancini, L., Ranaldo, A., and Wrampelmeyer, J. (2016). The euro interbank repo market. Review of Financial Studies, 29(7):1747-1779.

Martin, A., McAndrews, J., Palida, A., and Skeie, D. (2015). Federal Reserve Tools for Managing Rates and Reserves. IMES Discussion Paper Series 15-E-08, Institute for Monetary and Economic Studies, Bank of Japan.

Mersch, Y. (2017). Ructions in the repo market - monetary easing or regulatory squeezing? Speech by Yves Mersch, Member of the Executive Board of the ECB, at the GFF summit, Luxembourg, 26 January $201 \%$.

Munyan, B. (2015). Regulatory Arbitrage in the Repo Market. Working Papers 15-22, Office of Financial Research, US Department of the Treasury.

Pelizzon, L., Subrahmanyam, M. G., Tomio, D., and Uno, J. (2018). Central bank-driven mispricing. SAFE Working Paper Series 226, Research Center SAFE - Sustainable Architecture for Finance in Europe, Goethe University Frankfurt.

Poole, W. (1968). Commercial Bank Reserve Management In A Stochastic Model: Implications For Monetary Policy. Journal of Finance, 23(5):769-791.

Reuters (2018). ECB says the excess cash it created could backfire: Coeure.

Singh, M. (2011). Velocity of Pledged Collateral; Analysis and Implications. IMF Working Papers 11/256, International Monetary Fund.

Spies, M. and Sian, H. (2017). Pspp or regulations: What's driving repo markets? Technical report, Citi, Euro Rates Strategy Focus, 23 March 2017.

Stein, J. C. (2012). Monetary Policy as Financial Stability Regulation. The Quarterly Journal of Economics, 127(1):57-95.

Vari, M. (forthcoming). Monetary policy transmission with interbank market fragmentation. Journal of Money, Credit and Banking. 


\section{A Regulation and the repo market}

Regulations of financial institutions and financial markets may impact the repo market in many ways: by incentivizing financial institutions and other market participants to hold "safe assets" on balance sheets, by limiting collateral reuse, by restricting or penalizing repo leverage. In the following sections, we detail some of these regulations and their likely impact on the repo market functioning.

\section{A.1 Regulatory demand of high-quality liquid assets}

Some regulatory constraints incentivize financial intermediaries to hold bonds of the highest quality (in terms of credit and liquidity) and thus might prevent them from lending these bonds out on the repo market.

- The Liquidity Coverage Ratio (LCR), which is part of the Basel III regulations, forces banks to hold High Quality Liquid Assets (HQLAs), mostly government bonds. Its phasing-in started in 2015 and it will become fully effective in 2019. As of December 2016, the stock of HQLA assets held by European banks already equals $139.5 \%$ of LCR requirements. At the same date, about 2.5 trn EUR of assets are classified as HQLAs, so as of December 2016, banks are required to hold around 1.8 trn EUR of HQLAs under the $\mathrm{LCR}^{33}$. Collateral borrowed in a reverse repo transaction is counted in the stock of HQLA assets of a bank if it is eligible as such. ${ }^{34}$. But, as underlined in Klee et al (2017), borrowing a HQLA asset via a reverse repo does not change the LCR ratio:treatment of collateral in case of repo transactions for LCR purposes implies that lending in the repo market (in which the underlying collateral is in the HQLA category) has no effect on a bank's LCR. Overall, the marginal effect of the LCR implementation is expected not to be material on repo rates in the US. The consequence of LCR ratios enforcement on HQLA assets expected returns in the US is studied in Duffie and Krishnamurthy (2016). Fuhrer et al. (2017) find that for the Swiss securities market, qualifying as a HQLA asset decreases on average the yield of a security by around 4 bps.

- The mandatory posting of collateral to fund initial margins (IMs) and variation margins (VMs) of OTC derivatives positions, as prescribed in the European Market Infrastruc-

\footnotetext{
${ }^{33}$ https : //Www . eba. europa . eu/documents/10180/1720738/EBA+Report+of+CRDIV-CRR+Basel+III+ monitoring+exercise+-+December+2016.pdf

${ }^{34}$ http://www.bis.org/publ/bcbs284.pdf
} 
ture Regulation (EMIR), might also play a role. Such requirements entered into force in 2014. Margins collected by the Central Clearing Counterparties (CCPs) are subject to haircuts, which increase with their risk ${ }^{35}$. Participants are likely to post as margins their highest quality holdings, which will end up on the balance sheets of CCPs. While they are allowed to re-use IMs and VMs under certain conditions, it is in practice limited. Such assets are more likely to remain on their balance sheets.

\section{A.2 A limit on the re-use of repo collateral}

'Re-use' is the activity performed on the repo market whereby agents having borrowed a security will lend it again. Re-use thus increases the supply of collateral on the repo market. Mutual Funds usually re-use the collateral they receive in the course of their securities lending and derivatives positions (the collateral mitigates the counterparty risk from those operations). The UCITS ${ }^{36}$ V regulation of mutual funds, which was enforced in March 2016, restricts the way they can re-use the collateral they receive. Re-use is permitted only if a collateral asset of at least the same quality is borrowed in exchange. Such a regulation is thus likely to decrease supply of collateral on the repo market.

\section{A.3 Restrictions or costs on repo leverage}

Other regulations impose a restriction or a cost on leverage, which can deter financial institutions from trading repo, because repo transactions increase bank's balance sheets.

- The new Money Market Funds regulation ${ }^{37}$, which was first drafted by the European Commission in November 2013, was ratified in April 2017 by the European Parliament. It creates pressures on the demand for short term assets, to meet daily and weekly liquidity criteria. It also imposes restrictions in the use of repurchase agreements, as MMFs (which encompass UCITS as well as AIFs ${ }^{38}$ ) can only invest in repos up to a limit of $10 \%$ of their assets.

- The Leverage Ratio (LR) imposes capital requirements primarily based on the size, not on the risk exposure of banks' balance sheets. Under the LR, banks must have a minimum leverage ratio of $3 \%$ (that minimum starts to kick in only in 2018, but since

\footnotetext{
${ }^{35}$ http://eur-lex.europa.eu/legal-content/EN/TXT/HTML/?uri=CELEX:32012R0648\&from=EN

${ }^{36}$ UCITS stands for 'Undertakings for Collective Investment in Transferable Securities'

${ }^{37}$ http: //eur-lex . europa. eu/legal-content/EN/TXT/PDF/?uri=CELEX : 32017R1131\&from=EN

${ }^{38} \mathrm{AIF}$ s stand for Alternative Investment Funds
} 
banks have to publish their leverage ratio since 2015, the $3 \%$ threshold has become a market reference). The impact of the LR on the repo market is documented in CGFS (2017): "repos lead to an expansion of bank's balance sheet, and therefore attract a capital charge for the intermediary under the leverage ratio. Banks can hence be expected to adjust prices or limit supply in response to this cost". To comply with the LR, we expect banks to scale down both repos and repo trades intermediation activities. Repo trades can still be netted, which removes them from the scope of the LR Fernandez (2017). The impact of the LR on banks' repo operations has already been documented in Baklanova et al. (2016) for US and UK markets. They find that the reduction in repo activity for dealers is stronger for safer collateral than for riskier collateral. For the euro area, CGFS (2017) stresses that "activities with low risk weights are more likely to be affected by balance sheet constraints than by risk-weighted capital requirements".

\section{A.4 Window-dressing around reporting dates}

In Europe, compliance with regulation is most of the time binding at specific dates, mainly month-ends, quarter-ends or year-ends. For instance, the LCR ratio has to be reported at month-ends, while under the LR, European banks must report balance sheets at quarterends. This can entice financial institutions to do some form of window-dressing around reporting dates (see for instance Munyan (2015), Duffie and Krishnamurthy (2016) Klee et al. (2016)). This would be consistent with end-of-quarters volatility that we observe in the repo market. Spies and Sian (2017) underline that "banks have to report LCR ratios on a monthly basis which leads to heightened volatility in repo markets during the last days before a reporting date". They observe in US Money Market Funds data changes in volumes at quarter-ends, noting for European banks "clear seasonality at end-quarter, as banks' activity as repo counterparty fell dramatically". CGFS (2017) states that in jurisdictions where banks' reporting occurs at quarter-ends, there are "incentives for banks to contract their repo exposure on these dates, giving rise to short-lived but sharp spikes in repo volumes and prices". On year-ends, additional balance sheet constraints add to the more frequent requirements. A prominent example is the contribution of banks to the Single Resolution Fund (SRF). Each year, the contribution is calculated based on the size of banks deposits. ${ }^{39}$.

\footnotetext{
${ }^{39}$ http: //www .europarl .europa.eu/RegData/docs_autres_institutions/commission_europeenne/ swd/2014/0327/COM_SWD(2014)0327(PAR3)_EN.pdf
} 